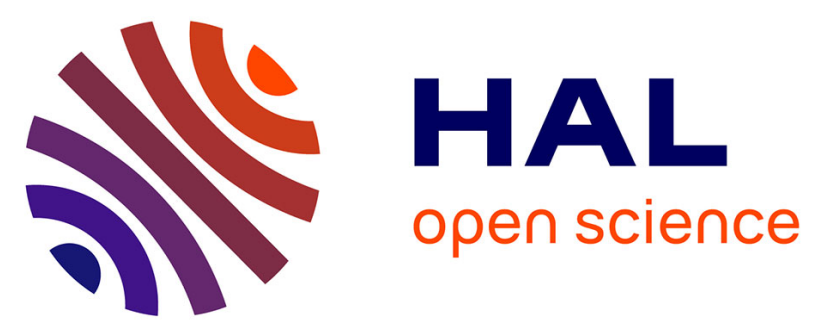

\title{
Role of platelets in cancer and cancer-associated thrombosis: Experimental and clinical evidences.
}

Soraya Mezouar, Corinne Frère, Roxane Darbousset, Diane Mege, Lydie

Crescence, Francoise Dignat-George, Laurence Panicot-Dubois, Christophe

Dubois

\section{To cite this version:}

Soraya Mezouar, Corinne Frère, Roxane Darbousset, Diane Mege, Lydie Crescence, et al.. Role of platelets in cancer and cancer-associated thrombosis: Experimental and clinical evidences.. Thrombosis Research, 2016, 139, pp.65-76. 10.1016/j.thromres.2016.01.006 . hal-01455290

\section{HAL Id: hal-01455290 \\ https://hal-amu.archives-ouvertes.fr/hal-01455290}

Submitted on 13 Feb 2020

HAL is a multi-disciplinary open access archive for the deposit and dissemination of scientific research documents, whether they are published or not. The documents may come from teaching and research institutions in France or abroad, or from public or private research centers.
L'archive ouverte pluridisciplinaire HAL, est destinée au dépôt et à la diffusion de documents scientifiques de niveau recherche, publiés ou non, émanant des établissements d'enseignement et de recherche français ou étrangers, des laboratoires publics ou privés. 
Role of Platelets in Cancer and Cancer-associated Thrombosis: Experimental and Clinical Evidences

Soraya Mezouar ${ }^{(1)}$, Corinne Frère ${ }^{(1)}$, Roxane Darbousset ${ }^{(1)}$, Diane Mege ${ }^{(1)}$, Lydie Crescence ${ }^{(1)}$, Françoise Dignat-George ${ }^{(1,2)}$, Laurence Panicot-Dubois ${ }^{(1)}$ and Christophe Dubois ${ }^{(1)}$.

${ }^{1}$ Aix-Marseille Université, INSERM UMR-S1076, Vascular Research Center of Marseille, 27 Boulevard Jean Moulin, 13385 Marseille, France.

${ }^{2}$ Laboratoire d'Hématologie, Centre Hospitalo-Universitaire Conception, 385 Boulevard Baille, 13385 Marseille, France.

\section{Abstract: 144 words}

Text: 5533 words 


\begin{abstract}
The primary hemostatic function of platelets has been recognized for more than a century, but increasing experimental and clinical evidences suggest that platelets are also important mediators of cancer. Cancer indeed influences platelet physiology, and activated platelets participate in each step of cancer development by promoting tumor growth, angiogenesis, metastasis, and cancer-associated thrombosis. Based on both the results of numerous experimental models addressing the involvement of platelets in cancer progression and the results of epidemiologic studies on the use of anti-platelet drugs to prevent cancer, platelets have been proposed as a potential target to reduce the short-term risk of cancer, cancer dissemination and cancer mortality. However, the cancer-associated thrombosis and the risk of bleeding due to anti-platelet drugs are not enough evaluated in experimental models. Therefore, the interesting contribution of platelets to cancer and cancer-associated thrombosis requires the standardization of preclinical and clinical models.
\end{abstract}

Keywords: Platelet, cancer, immunothrombosis, experimental models, clinical investigations 


\section{Introduction}

Platelets are small anucleated blood cell fragments released from bone marrow megakaryocytes that circulate in the bloodstream at concentrations of 150 to $350 \times 10^{9} / \mathrm{L}$. Their primary hemostatic function has been recognized for more than a century. In 1882, Bizzozero first observed them microscopically in the circulating blood of living animals and demonstrated their role in promoting thrombosis in vivo.

After vascular injury, platelets are able to rapidly adhere to sites of endothelial disruption via the interaction of platelet glycoprotein (GP)Ib-V-IX and von Willebrand factor (vWF). This results in platelet translocation on the vessel wall. Firm adhesion activates collagen receptors GPVI and $\alpha_{2} \beta_{1}$. These receptor-ligand interactions initiate intracellular calcium mobilization, cytoskeletal reorganization, shape change, degranulation, up-regulation of integrins, such as $\alpha_{\mathrm{IIb}} \beta_{3}$, and the release of soluble platelet agonists, such as thrombin, $\underline{\text { adenosine di-phosphate (ADP) and thromboxane } \mathrm{A}_{2}}\left(\mathrm{TXA}_{2}\right)$. These agonists amplify the platelet activation response through specific G-protein-coupled receptors. In addition, local thrombin generation also enhances platelet activation through proteolytic cleavage and the activation of protease activated receptors (PARs). Finally, activated platelets form stable aggregates through the linking of $\alpha_{\mathrm{IIb}} \beta_{3}$ with fibrinogen. This hemostatic plug is what prevents excess blood loss.

In addition to their central role in hemostasis and thrombosis, platelets contribute to the development of a variety of diseases, including malignancies. Accumulating experimental and clinical evidences support the hypothesis that platelet activation during cancer (in response to endothelial or epithelial injury) promotes disease progression. The concept that platelets may participate in cancer biology is not new since experimental reduction in platelet count or platelet function was found to have anti-metastatic effects in animal models. Gasic et al. first provided in 1968 experimental evidence for the role of platelets in cancer [1]. They demonstrated in a mouse model that intravenous injection of neuramidase leading to thrombocytopenia inhibited metastasis. Several thrombocytopenic mouse models later confirmed that decreased platelet count results in inhibited tumor growth, angiogenesis and metastasis [2]. These models are summarized in the Table 1. Numerous in vitro and in vivo studies further investigated the platelet-mediated mechanisms of cancer progression including the tumor growth, the angiogenesis and the metastasis development.

In line with experimental data, cancer patients often present thrombocytosis and increased markers of platelet activation including P-selectin and platelet-derived 
microparticles (PMPs), reflecting a platelet activation state during the course of the disease [8]. Platelets are additionally thought to contribute to the hypercoagulable state frequently observed in cancer patients, leading to an increase risk of venous thromboembolism (VTE) which is a leading cause during the course of the disease [9]. Finally, the results of numerous randomized clinical trials demonstrated that anti-platelet drugs might reduce the incidence of some cancers [10].

This review summarizes the bidirectional interactions between cancer and platelets. Cancer indeed influences platelet physiology, and activated platelets participate in each step of cancer development by promoting tumor growth, angiogenesis, metastasis, and cancerassociated thrombosis. The potential of platelets as a target in cancer therapy is further discussed. 


\section{I-Experimental evidences}

a) Effects of cancer on platelets

It has been widely demonstrated that tumor cells have the ability in vitro to induce platelet activation and aggregation; this mechanism is referred to as tumor cell-induced platelet aggregation (TCIPA). Different types of tumor cell lines were shown to induce TCIPA, such as pancreatic [11], colorectal [12] and kidney cancer cell lineages [13]. The tumor cells' ability to induce platelet aggregation was found to be dependent on their metastatic potential [14]. Furthermore, several molecular pathways are involved in platelet activation and TCIPA, including the thrombin, ADP, TXA 2 , metalloproteinases (MMPs) and tissue factor (TF) pathways, which seem to be tumor-cell specific and sometimes mutually exclusive [15].

Thrombin. Thrombin is a multi-functional serine protease that converts fibrinogen to fibrin. Thrombin also activates other proteins in the coagulation cascade, such as coagulation factors V, VIII, XI, and XIII. It is also arguably the most effective agonist for platelet activation via the activation of PARs. It triggers shape change, the release of platelet activators, such as ADP, serotonin and $\mathrm{TXA}_{2}$, as well as chemokines and growth factors. It also mobilizes Pselectin and CD40 ligand to the platelet surface and leads to the activation of integrin $\alpha_{\mathrm{IIb}} \beta_{3}$. Cancer cells have been shown to directly secrete thrombin which may activate the coagulation cascade and platelets [12]. Pancreatic and lung cancer cell lines in particular were found to induce platelet activation via thrombin secretion [12]. These interactions activate PARs on both platelets and tumor cells. In cancer, thrombin signaling was also implicated in tumor cells malignancy and metastasis [16]. Concordantly, the thrombin generation potential is increased in cancer patients and decreased at both prophylactic $(40 \mathrm{mg})$ and therapeutic (80

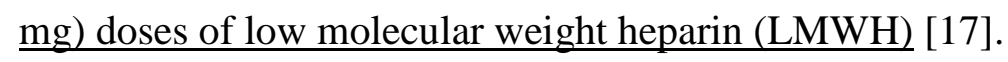

ADP. ADP is stored in platelet-dense granules and is released upon platelet activation. ADP interacts with platelet receptors $\mathrm{P} 2 \mathrm{Y}_{12}$ and $\mathrm{P} 2 \mathrm{Y}_{1}$, leading to platelet aggregation, shape change and the release of $\mathrm{TXA}_{2}$. ADP is expressed by cancer cells and has been shown to contribute to TCIPA [12] [18]. The $\mathrm{P}_{2} \mathrm{Y}_{12}$ receptor was found to be involved in the induction of TCIPA by MCF-7 breast carcinoma cells [18]. The use of the ADP inhibitor apyrase strongly inhibits TCIPA [19].

Thromboxane A2. TXA $_{2}$ is overexpressed in numerous tumor cell lines and can enhance platelet activation and aggregation [20]. 
Matrix metalloproteinases. MMPs are involved in the degradation of the extracellular matrix [21]. Tumor cells express matrix metalloproteinases, such as MMP-2, MT1-MMP and MMP-9 which have been shown to be involved in platelet activation and TCIPA [19] [18] [22]. Breast cancer cells express MMP-1, which upregulates both GPIb- $\alpha$ and GPIIbIIIa and is also involved in ADP release via a positive feedback pathway that stimulates TCIPA. MMP-2 expressed by HT-1080 human fibrosarcoma cells and MCF7 breast carcinoma cells also induces TCIPA [19] [18]. Generation of MMP-2 has also been correlated with an increase in TCIPA in prostate cancer patients [23].

Tissue factor. TF is the main activator of the coagulation cascade in physiologic and pathologic conditions. The coagulation cascade is indeed initiated as soon as TF comes into contact with circulating activated FVIIa. This initial contact creates the TF-FVIIa complex, which directly converts FX to activated FXa. Factor Xa complex, with activated FVa and calcium, catalyzes the conversion of prothrombin to thrombin, leading to fibrin formation, platelet activation and thrombus generation. Numerous cancer cell lines express TF and release TF-bearing microparticles released into the circulation. It should be noted that TF has been demonstrated to have a key role in cancer [24].

$\underline{\text { Several experimental studies investigate the inhibition of platelet activation and }}$ aggregation and show its impact on each steps of the cancer development. These studies focusing on the activating proteins of the platelet receptors are summarized in the Table 2.

\section{b) Effects of platelets on cancer}

Cancer promotes platelet activation and activated platelets participate in each step of cancer progression.

\section{- Tumor growth}

Recently, Stone et al. demonstrated in murine ovarian cancer models that an abundance of platelets were present in the tumor microenvironment outside the vasculature [47]. When activated, platelets recruited to the tumor microenvironment can locally regulate tumor cell behavior and promote proliferation not only through paracrine signaling but also through direct contact with tumor cells [48][49]. Activated platelets and PMPs indeed release numerous mitogenic proteins and growth factors from their $\alpha$-granules, including plateletderived growth factor (PDGF)-A and PDGF-B, insulin-like growth factor (IGF)-I, PF4, vascular endothelial growth factor (VEGF), transforming growth factor- $\beta$ (TGF- $\beta 1$ ), stromal cell-derived factor-1 (SDF-1) and angiopoietin, which were found to be involved in tumor 
growth in several in vitro and in vivo studies [50] [51] [52] summarized in Table 3. For example, platelets were found to release SDF-1 [71], which binds primarily to CXCR4 and induces intracellular signaling through several divergent pathways. This triggers responses related chemotaxis, cell survival and/or proliferation, intracellular calcium, and gene transcription [72]. Cho et al. recently demonstrated that platelets enhance the proliferation of ovarian cancer cells in vitro via a mechanism involving TGF- $\beta$; similarly, they also observed that ovarian tumors from patients with thrombocytosis had an increased proliferative index compared to those with normal platelet counts [73]. Regarding tumor growth, platelets not only secrete growth factors but also release toxic cytokines that inhibit tumor growth. Angiostatic $\underline{\mathrm{PF} 4}$ was shown to inhibit tumor cell proliferation and migration. Because of this, it was proposed as an adjuvant cancer therapy [74]. Co-culture of platelets with melanoma and prostate tumor cells inhibited proliferation of tumor cells because of soluble factors released from platelets as well as direct contact between platelets and tumor cells [74]. This inhibition resulted from a tumor cell cycle arrest in the GO/G1 phase. There conflicting results in the literature concerning this. While some studies found that platelets decrease the cancer cell proliferation through their cytotoxic effects, others demonstrated that platelets increase cancer cell proliferation [75] [74].

Unfortunately, there is a paucity of data concerning the effects of platelet direct interaction with tumor cells on tumor growth. A few studies have investigated the role of $\alpha_{\mathrm{IIb}} \beta_{3}$ in tumor growth [76] and suggest that a real direct interaction of platelets and cancer cells exists and needs to be further explored in vivo.

\section{- Angiogenesis}

Angiogenesis is defined as the formation of new microvessels from pre-existing vasculature [77]. This process appears to be crucial for primary tumor growth $>2 \mathrm{~mm}$ [78]. It not only prevents both hypoxia and necrosis but also allows for the delivery of proteases and cytokines that contribute to further intravasation, extravasation and dissemination. Evidence supporting platelet participation in tumor neovascularization have accumulated over the years [77]. During angiogenesis, platelets come into contact with subendothelial prothrombotic structures, such as collagen in new vessels with abnormal configuration. This causes changes in the laminar blood flow, specifically by increasing shear stress, and the VEGF-induced release of $\mathrm{vWF}$ by endothelial cells, leading to platelet activation [79]. Activated platelets then release the myriad of angiogenesis-regulating proteins contained in their granules. 
Cytokines exerting pro-angiogenic effects include VEGF, PDGF, TGF, epidermal growth factor, angiopoietin-1, IGF-I, sphingosine-1-phosphate, and MMPs; and anti-angiogenic effects include PF4, thrombospondin-1 (TSP-1), endostatin, serotonin, plasminogen activator

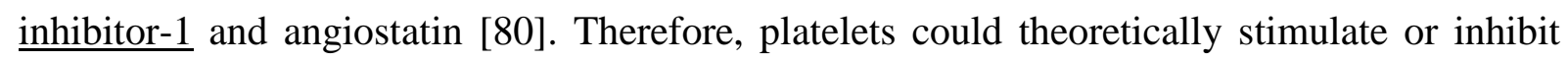
angiogenesis; however, in most studies, the pro-angiogenic effects prevail over the antiangiogenic effects. In vitro, activated platelets are able to induce tube formation of human umbilical vein endothelial cells in matrigel tube formation assays by both the secretion of endothelial stimulating factors and direct cellular interactions [81]. In aortic ring assays, platelets, platelet releasates and PMPs all induced a marked increase in angiogenesis [82] [83]. Concordantly, Kisucka et al. used cornea and matrigel assays to observe significantly reduced angiogenic activity in thrombocytopenic mice. This suggests that the presence of platelets stimulates angiogenic vessel growth [84].

VEGF plays a crucial role in regulating angiogenesis. Interestingly, in a meta-analysis, Kut et al. found an increase in platelet VEGF in cancer patients compared to controls [85]. The concentration of VEGF in the platelets of cancer patients was $413000 \mathrm{pg} / \mathrm{ml}$ compared to $216000 \mathrm{pg} / \mathrm{ml}$ in healthy controls [85]. This pro-angiogenic factor may be a potential biomarker in the detection and monitoring of cancer because platelet VEGF was found to predict tumor progression [86]. PDGF has also been associated with tumor growth and angiogenesis in many studies however the involvement of platelet-derived PDGF is not clearly identified in vivo [87]. The sources of platelet angiogenic factors are not yet fully understood, but in addition to uptake, it was demonstrated that enhanced production by megakaryocytes could contribute to the platelet angiogenic content [88].

Recently, a study of Italiano et al. aimed to elucidate the regulation of both anti- and pro-angiogenic factors release [89]. The authors demonstrated that the release of different types of angiogenic factors was triggered by different stimuli, specifically PAR-1 and PAR-4 [89]. PAR-4 stimulation led to the secretion of anti-angiogenic proteins, whereas the activation of PAR-1 led to the release of pro-angiogenic factors, such as VEGF.

\section{- Metastasis}

The highly complex process of metastasis includes the detachment of cancer cells from the primary tumor, intravasation into the lumen of blood vessels, intravascular migration, arrest in distant capillaries, and finally, extravasation into the surrounding tissue. While the lymphatic spread of cancer cells is observed in human tumors and used as an 
important prognostic marker for disease progression, dissemination via the hematogenous circulation appears to represent the major mechanism of metastasis [90]. However, because of the high shear forces and immune system surveillance, the bloodstream is an unfavorable medium for circulating cancer cells; only $0.1 \%$ survive in the circulation [91].

Today there is persuasive evidence that platelets contribute to the metastatic potential of tumor cells at each phase of the metastasis. The first experimental proof-of-concept was provided by Gasic in 1968 [1]. Others discovered tumor cells in thrombi and postulated a relationship between platelets and tumor cells. Numerous studies further demonstrated that platelet blockade or depletion inhibits metastasis [92]. The connection between platelets and circulated cancer cells has since been widely demonstrated [92]. This process is initiated by a direct interaction between platelets and cancer cells. Inhibiting this interaction was demonstrated to impact on the metastatic process (Table 4). Normally, resting platelets circulate within the vasculature and are prevented from binding to the vascular wall by endothelial cells. During cancer progression, platelets present an abnormal activated state that leads to the formation of platelet-cancer cell aggregates, which are crucial in the metastatic process.

\section{-Pre-metastatic niche formation}

Ten years ago, two important studies found that tumor primary cells secreted metastasis-related proteins to the target organ [114]. These proteins were shown to stimulate bone-marrow-derived cells to migrate and formed metastatic niches. Kerr et al. demonstrated, in three mouse models of tumor-induced bone formation, that platelets have a role in governing pre-metastatic tumor communication [115]. More recently, Labelle et al. showed that secretion of CXCL5 and CXCL7 chemokines by platelets upon contact with tumor cells induce granulocyte recruitment and the formation of early metastatic niches [116].

\section{-Tumor-platelet interaction during the intravascular phase of metastasis}

Tumor cells circulating within the vasculature are exposed to high shear stress that can disrupt their membranes. They also have to evade immune surveillance. Because of this, the activation of platelets by tumor cells (previously detailed in the text) and the adhesion of platelets to tumor cells are crucial mechanisms allowing circulating cancer cells to survive in the bloodstream. Palumbo et al. found that tumor cell survival and metastasis formation was inhibited in mice with deficient platelet activation (Gaq, deficient mice) [117]. TCIPA results 
in platelets coating the tumor cells, protecting them from neutralization by natural killer cells (NKs) and tumor necrosis factor- $\alpha$ mediated cytotoxicity [92]. NKs are the main anti-tumor cells and directly interact with cancer cells [118]. Impaired activity or depletion of NK cells in mice results in a significant increase in metastasis [119], and immunologic or genetic depletion of NKs was demonstrated to restore metastatic potential in tumor cells. Moreover, platelets that aggregate around tumor cells are able to secrete TGF- $\beta$, which downregulates NK cytotoxicity and interferon- $\gamma$ production via the downregulation of the NKG2DL receptor on NKs [120]. TCIPA also inhibits the maturation of dendritic cells previously implicated in antigen presentation to the immune system [121]. These results are consistent with epidemiological studies demonstrating an increased risk for cancer in patients with decreased NK counts [117].

Furthermore, platelets express high levels of major histocompatibility complex-1 (MHC-1), and platelets attached to tumor cells have been shown to transfer MHC-1 to tumor cells [123]. MHC-1 protects tumor cells from recognition by NK cells [123] and other cells and from the inflammatory response. Several other platelet receptors are also expressed on tumor cells, a phenomenon referred to as platelet mimicry, which allows the tumor cell to escape from immune surveillance [124].

\section{-Tumor-platelet interaction during the tumor cell arrest and extravasation}

TCIPA not only permits cancer cells to survive in the bloodstream, but it also facilitates their arrest and extravasation to promote metastasis. TCIPA first shields cancer cells from high shear forces that could damage them. Platelet-cancer cell aggregates resulting from TCIPA can also embolized into the microvasculature, promoting their arrest and adhesion to endothelial cells for transmigration to the metastasis site [125].

The rolling and tethering of tumor cells to the endothelium are primarily mediated by P-selectin [103]. Studies in P-selectin-deficient mice showed a decrease in metastasis in a colon carcinoma model [126]. After this first interaction, platelet GP-Ib $\alpha, \alpha_{\mathrm{IIb}} \beta_{\mathrm{III}}$ integrin and vWF all contribute to firm adhesion [127]. In addition, tumor cells express several "platelet receptors", such as $\alpha_{\text {IIb }} \beta_{\text {III }}, \alpha_{v} \beta_{3}$ or GPIb- $\alpha$ [128]. This "platelet-mimicry", previously involved in escaping the immune system, also contributes to the tumor cells' interaction with leukocytes, platelets and endothelial cells to promote extravasation [124]. Other platelet receptors, such as PAR-1 are expressed by cancer cells and induce the expression of several integrins that contribute to their adhesion to endothelial cells [129]. Platelet $\alpha_{2} \beta_{1}$ was found to 
be expressed in prostate cancer cells, suggesting a direct interaction of cancer cells with subendothelial collagen [130]. Factors released by activated platelets confer several advantages to tumor cells during the extravasation process. Platelets can both increase and decrease vascular permeability via granule release [4]. After TCIPA, activated platelets release their dense granules, such as ATP, which interact with the endothelial receptor $\mathrm{P}_{2} \mathrm{Y}_{2}$. This interaction promotes the opening of endothelial cell junctions to facilitate cancer cell transmigration [131]. Extravasation is decreased when $\mathrm{P}_{2} \mathrm{Y}_{2}$ receptors are absent or in Munc13-4 deficient mice, in which the release of platelets' dense granules is inhibited [131]. Another important platelet mediator involved in tumor cell aggregation is serotonin, which is also stored in dense granules. Blocking serotonin receptors leads to inhibited experimental metastasis, which is consistent with the fact that cancer patients have increased serotonin levels in the plasma [132]. Activated platelets also release growth factors contained in their $\alpha$-granules. These include TGF- $\beta$, lysophosphatidic acid (LPA), Sphingosine-1 and MMPs. The role of LPA and Sphingosine-1 has been demonstrated as an inhibitor of vascular leakage [133]._LPA, a platelet bioactive lipid, is increased in ascites fluid and plasma from ovarian, endometrial and cervical cancer patients [134] and is strongly involved in the cell proliferation, survival and migration during cancer [135]. The blocking of its receptors suppress tumor metastasis and show the essential contribution of the LPA in the vicious circle of intercellular stimulation between platelets and cancer cells [136]. Activated platelets also secrete MMPs, which contribute to tumor cell invasion by degrading the vessel and remodeling the tissue after transmigration [137]. Platelets are also suggested to induce the epithelial-mesenchymal transition implicated in tumor cell invasion by direct interaction or by TGF- $\beta$ and VEGF release [138]. Altogether, these mechanisms promote metastasis. Some studies demonstrate that metastasizing tumor cells can also reenter the bloodstream to induce additional metastasis or return to the primary tumor [91].

\section{c) Experimental animal models targeting platelets to inhibit cancer progression}

Based on experimental data, targeting platelets to inhibit cancer progression and metastasis appears to be a promising approach. Because of the biological complexity of platelet involvement in these processes, numerous animal models have been developed in addition to in vitro approaches.

Numerous studies aimed to target key platelet actors using knockdown mice, antibodies or anti-platelet drugs (Table 1-2-3 and 4). The in vitro studies were mainly based on the use of washed platelets and cancer cell lines. They focused on tumor cell-platelet 
interactions, adhesion, TCIPA, invasion, proliferation and platelet activation (receptor expression or granules components). Protocols to obtain washed platelets strongly varied across studies, particularly in the anticoagulants, anti-platelets and buffers used. Because it is difficult to work with platelets, it would be important to further standardize washed platelets protocols as well as the activation markers used to compare results.

The use of animal models has yielded many important insights into the potential targeting of platelets to treat cancer. In tables of this present review, we summarized the main studies evaluating platelets as a therapeutic target for inhibiting tumor growth and metastasis development. In addition to the type of experimentation and the impact on malignancy, we also quoted the experimental models used. Surprisingly, the majority of the in vivo studies is based on the use of the experimental metastasis model, and there were few studies investigating cancer-associated thrombosis. Most of the experimental studies showed that platelet inhibition slows cancer progression, supporting a rational for clinical studies to evaluate the use of anti-platelet drugs in cancer patients. .

The most-used model of transplantable cancers to study metastasis development is based on the injection of tumor cells directly into the systemic circulation. This model provides several advantages, such as speed, but it has numerous limitations. The tail vein injection of tumor cells first results in microthrombi due to platelet aggregation. The direct injection of a large number of tumor cells does not mimic the process of spontaneous metastasis from a primary site. Injected tumor cells also induce exclusively pulmonary metastases that appear in approximately 15 days. Consequently, this model has previously been described as a model in which multiple primary tumors develop in the lung. This model only allows for a limited examination of the post extravasation step and the presence of a thrombocytopenia due to platelet consumption in microthrombi do not allow to study the involvement of platelets during the progression of the disease. In addition, the mortality of the animals is very high. [139].

Models that more closely mimic human cancers, particularly the metastatic process, are required to evaluate platelets as a therapeutic target. Many studies have demonstrated that orthotopic models reproduce the rapid growth of local tumors and spreading of metastases in humans [140]. With a longer time for metastasis (average time of metastasis become evident at 25 days), the orthotopic animal model induces spontaneous metastasis and appears more relevant in preclinical studies. For example, Yamamoto et al. showed differences in MMP 
expression in metastasis, following the experimental metastasis model, in comparison to spontaneous metastasis [141].

\section{II- Clinical evidences}

$\underline{\text { In line with experimental data, clinical data also clearly suggest a role for platelet in cancer }}$ and cancer-associated thrombosis.

\section{a) Thrombocytosis and platelet activation markers during cancer}

An increased platelet count has been first observed in cancer patients for decades. More than 100 years ago, Tranum and al. indeed described that thrombocytosis was associated with malignancy [142]. Furthermore, in the 1960s Levin et al. found that $40 \%$ of patients with inoperable solid malignancies had an increased platelet count (higher than $\underline{400 \times 10^{9} / \mathrm{L}}$ ) [10]. High platelet counts were since observed at the time of diagnosis in many patients with solid tumors and may precede the diagnosis [143]. Thrombocytosis is correlated with poor survival and decreased response to surgery and chemotherapy in lung, breast, colorectal, renal and gastric cancers [143]. These data suggest a potential direct role for platelets in the pathogenesis of the disease. Until recently, cancer-associated thrombocytosis was considered to be a paraneoplastic phenomenon, but specific molecular pathways have been identified - specifically the interleukin (IL)-6 pathway-by which tumors can promote platelet production and activation [143].

Platelet activation was also increased in cancer patients. Several clinical studies investigated the levels of biomarkers of platelet activation, such as soluble P-selectin, CD40 ligand, PF4, TSP-1 and $\beta$-thromboglobulin ( $\beta$-TG) in the blood of cancer patients [144] [145]. An increase in soluble P-selectin, CD40 ligand and $\beta$-TG levels but no change in PF4 levels was observed in cancer patients but not in healthy controls, suggesting that ongoing platelet activation occurs in cancer patients. Platelet P-selectin expression was also increased in cancer [146], and TSP-1 levels were increased in pancreatic and colorectal cancers but not in lung cancer [147]. Interestingly, platelet activation correlated with metastatic potential in both in vitro and in vivo studies [14].

Several studies have investigated the role of PMPs in cancer and cancer-associated thrombosis [148]. PMPs levels are dramatically increased in malignancy. An increase in PMPs has been found in gastric cancer [149] or prostate cancer [150]. PMPs levels have been 
associated with the presence of metastasis in gastric cancer patients and correlate with the severity of the disease better than vascular endothelial growth factor, IL-6, and RANTES (regulated on activation, normal T cell expressed and secreted) [149]. Furthermore, the overall survival of patients with hormone-resistant was found to be inversely related to the PMPs levels [150]. Interestingly, a flow cytometry study found that circulating PMPs counts decreased while the number of platelet aggregates increased [151].

\section{b) Platelet contribution to cancer-related thrombosis}

Various sources suggest that platelets also participate in the procoagulant stateassociated with cancer, which is responsible for VTE, a frequent cause of death in cancer patients [9]. Several platelet laboratory parameters were developed to predict the risk of VTE in cancer patients. First, platelet count was demonstrated to be a biomarker of cancerassociated thrombosis in independent studies. A prospective study of patients starting chemotherapy shows that platelet count, prior to chemotherapy, increases risk of VTE [152]. Numerous other studies indicate an association between thrombocytosis, risk of VTE and survival in cancer patients. Second, several biomarkers of platelet activation were found to be associated with VTE risk. In a prospective study of 687 cancer patients with either recently diagnosed cancer or recently relapsed cancer, increased soluble P-selectin levels (>53.1 $\mathrm{ng} / \mathrm{mL}$ ) were predictive of VTE thromboembolism [153]. A clinical study in pancreatic cancer patients also demonstrated that high levels of PF4 $(>11 \mathrm{kU} / \mathrm{mL})$ were associated with an increased risk of VTE. A recent report by the Vienna cancer and thrombosis studies demonstrated in a large cohort of cancer patients that a decreased mean platelet volume was associated with VTE risk [154].

In 2008, Khorana et al. developed a risk assessment model for prediction of VTE in cancer patients at the time of chemotherapy initiation [155]. This score is based on simple clinical variables (type of cancer, body mass index) and complete blood count including platelet counts (pre-chemotherapy platelet count $>350 \times 10^{9} / \mathrm{L}$ ). It was later expanded and Pselectin levels $(53.1 \mathrm{ng} / \mathrm{mL})$ have been incorporated (Modified Khorana score) [156]. However, P-selectin levels are not used in clinical practice because of their poor standardization, their low availability and their high cost.

Several mechanisms have been proposed for platelet involvement in venous thrombosis. First, activated platelets exhibit a procoagulant surface by exposing negatively charged phospholipids that can induce thrombin generation leading to fibrin formation and 
clotting [157]. Second, platelet-leukocyte interactions appear to be crucial for platelet-rich microthrombi generation in adenocarcinoma mice because it was markedly diminished in Por L-selectin-deficient mice [158]. Third, platelet adhesion to endothelium was demonstrated to be a critical step for deep vein thrombosis in mouse models [82]. Finally, platelets were found to induce formation of Neutrophil Extracellular Traps [159], which may promote the establishment of a pro-thrombotic state during cancer [160]. These finding suggest a crosstalk between inflammation and platelet-dependent thrombosis in cancer (Figure 1). Thus, cancer development is composed of pro-thrombotic and pro-inflammatory states, confirming the emerging concept of immunothrombosis.

\section{c) Antiplatelet drugs and cancer prevention}

Over the last few decades, numerous clinical studies have emerged suggesting that taking aspirin daily may substantially lower cancer incidence, metastasis and mortality. A 2012 meta-analysis [161] of 5 randomized clinical trials (RCTs) of aspirin versus no aspirin in the prevention of cardiovascular diseases included 17,285 participants. Aspirin treatment lowered the risk of cancer with distant metastasis (all cancers hazard ratio (HR) 0.64, 95\% confidence interval (CI) 0.48 to 0.84 ). When patients were stratified by cancer type, the risk reduction remains statistically significant for adenocarcinoma (HR $0.54,95 \%$ CI 0.38 to 0.77 ) but not for other solid cancers (HR $0.82,95 \%$ CI 0.53 to 1.28). In adenocarcinoma patients, not only the risk of metastasis upon initial diagnosis (HR $0.69,95 \%$ CI 0.50 to 0.95 ) but also the risk of future metastasis in patients without initial metastasis (HR 0.45 , 95\% CI 0.28 to 0.72 ) and the risk of death by cancer (HR $0.50,95 \%$ CI 0.34 to 0.74 ) was reduced. In another meta-analysis of 51 RCTs including 77,549 participants [161], daily aspirin treatment significantly reduced cancer deaths (odds ratio (OR) $0.85,95 \%$ CI 0.76 to 0.96). Interestingly, when patients were stratified by follow-up duration, aspirin's benefit in cancer mortality remained significant only for $>5$ years of follow-up (OR $0.63,95 \%$ CI 0.49 to 0.82). The putative mechanisms explaining aspirin benefits in cancer include inhibition of cyclooxygenase-1 and -2. In contrast, the randomized Physicians' Health Study [162] and the Women's Health Study [163] found no association between the use of aspirin and incidence of total, breast, colorectal, or other site-specific cancers. Several large clinical trials including the Cancer prevention project 3 (CAPP3), the aspirin for dukes $\mathrm{C}$ and high risk dukes $\mathrm{B}$ colorectal cancer (ASCOLT), the aspirin in reducing events in the elderly (ASPREE) and the aspirin and esomeprazole chemoprevention in barrett's metaplasia (AspECT) studies have been launched to evaluate whether aspirin use can reduce the risk of cancer incidence and 
death due to cancer. Several important questions must still be answered before aspirin can be considered as cancer adjuvant therapy. Specifically, what dosage provides the best efficacy and safety, and who may benefit from aspirin use? It is important to note that the United State preventive services task force (USPSTF) recently post a draft recommendation statement (www.uspreventiveservicestaskforce.org) on recommendations for the use of aspirin to prevent cancer and will soon publish its final recommendation statement.

Moreover, aspirin may be used to prevent the risk of cancer-associated thrombosis in high-risk patients. Several studies have investigated the benefits of aspirin for the prevention of secondary VTE in the general population. A meta-analysis of the anti-platelet trialists' collaboration showed that aspirin reduces the risk of both deep vein thrombosis (DVT) and pulmonary embolism (PE) by approximately 40\% in high-risk patients [164]. More recently, the PEP study, including more than 17,000 patients undergoing surgery for hip fracture or elective arthroplasty, confirmed that aspirin reduces the risk of VTE by at least one-third [164]. However, the results concerning the effect of aspirin as the primary prevention of VTE are less clear. In a case-control study on determinants and interaction of venous thromboembolism, aspirin use was associated with a significant $50 \%$ decreased risk of VTE $(\mathrm{OR}=0.50$, 95\% CI O.34-0.74), whereas neither thienopyridines nor non-steroidal antiinflammatory drugs had a significant effect on VTE risk [165]. Conversely, The Women's Health Study, a randomized trial of low-dose aspirin for the primary prevention of cardiovascular disease and cancer in initially healthy women, found no significant decrease in VTE risk in patients treated with aspirin compared to the placebo [39]. The warfarin and acetyl salicylic acid trial was the first prospective, randomized, multicenter, double-blind, placebo-controlled study evaluating the use of $100 \mathrm{mg}$ of aspirin daily for the secondary prevention of VTE in patients in whom vitamin K antagonist therapy had been discontinued. This study demonstrated a significant reduction in recurrent VTE among patients treated with $100 \mathrm{mg}$ daily aspirin compared to the placebo. (HR=0.58, 95\% CI 0.36-0.93, $\mathrm{p}=0.02)$ [166]. The aspirin to prevent recruitment of venous thromboembolism trial only showed a nonsignificant reduction in the primary outcome of recurrent symptomatic DVT or PE in patients with an unprovoked VTE who had completed at least three months of anticoagulation therapy and received $100 \mathrm{mg}$ of aspirin daily compared to the placebo $(\mathrm{HR}=0.74,95 \% \mathrm{CI}$ O.52-1.05, $\mathrm{p}=0.09$ ). A combined analysis demonstrated both a clinically and statistically significant benefit of aspirin with a $32 \%$ reduction in rate of recurrent VTE $(\mathrm{HR}=0.68,95 \%$ CI $0.51-0.90$, $\mathrm{p}=0.007$ ) [167]. The results of an open-label randomized study in multiple myeloma patients treated with thalidomide suggest that aspirin is at least as effective as warfarin, compared to 
LMWH, for VTE prevention [168]. Concordantly, the national comprehensive cancer network guidelines recommend $81 \mathrm{mg}$ to $325 \mathrm{mg}$ of aspirin daily as an option only for multiple myeloma patients with one or no risk factors. 


\section{Conclusion}

In the present review, we aimed to summarize the main molecular mechanisms by which cancer cells activate platelets and platelets participate in cancer progression, as well as their role in promoting cancer-associated VTE.

Several markers that reflect platelet activation during cancer have been evaluated as potential biomarkers of cancer diagnosis, prognosis and cancer-associated VTE with promising results. However, most of these biomarkers are expensive and not well standardized and not easily measured in clinical practice.

Targeting platelets has otherwise been proposed as a promising area for the development of new anticancer and antithrombotic strategies that could improve care and survival for cancer patients. Animal models provide convincing results, but these results should be interpreted with caution because some of the animal models used are not representative of the physiopathological steps of cancer clinical history. Even if important meta-analysis studies have suggested that taking aspirin daily may substantially lower cancer incidence, metastasis and mortality, results from clinical trials evaluating the use of aspirin in cancer remain controversial. Additional double-blind, randomized controlled trials evaluating the use of anti-platelets drugs in combination with current chemotherapeutic drugs are required. It is important to note that the use of drugs to target platelets could expose patients to a non-negligible bleeding risk that is often overlooked in experimental studies. Other side effects of using drugs to target platelets should be taken into consideration in future randomized controlled trials evaluating the use of anti-platelets drugs in cancer patients. In the future, a personalized medicine approach, as that proposed by Wistuba et al. [169], will probably be developed to prevent, diagnose, treat and follow-up patients suffering from cancer. 


\section{Acknowledgments}

We thank Pr. Dominique Farge-Bancel for its critical review of this manuscript. The project was supported by the GFTC (Groupe Francophone Thrombose et Cancer), the ARC (Agence pour la Recherche sur le Cancer) and the FRM (Fondation de la Recherche Medicale) associations (grants to C. Dubois). This work was supported by grants from the institutional funding from INSERM, the Aix-Marseille University and the ANR (Agence Nationale pour la Recherche, grant number ANR-09-JCJC-0053 to C. Dubois). 


\section{Reference}

[1] G.J. Gasic, T.B. Gasic, C.C. Stewart, Antimetastatic effects associated with platelet reduction, Proc. Natl. Acad. Sci. U. S. A. 61 (1968) 46-52.

[2] S. Karpatkin, E. Pearlstein, P.L. Salk, G. Yogeeswaran, Role of platelets in tumor cell metastases, Ann. N. Y. Acad. Sci. 370 (1981) 101-118.

[3] M.L. Nierodzik, A. Klepfish, S. Karpatkin, Role of platelets, thrombin, integrin IIbIIIa, fibronectin and von Willebrand factor on tumor adhesion in vitro and metastasis in vivo, Thromb. Haemost. 74 (1995) 282-290.

[4] L.J. Gay, B. Felding-Habermann, Contribution of platelets to tumour metastasis, Nat. Rev. Cancer. 11 (2011) 123-134. doi:10.1038/nrc3004.

[5] G. Gasic, T. Gasic, Removal of sialic acid from the cell coat in tumor cells and vascular endothelium, and its effects on metastasis, Proc. Natl. Acad. Sci. U. S. A. 48 (1962) 1172-1177.

[6] B. Ho-Tin-Noé, T. Goerge, S.M. Cifuni, D. Duerschmied, D.D. Wagner, Platelet granule secretion continuously prevents intratumor hemorrhage, Cancer Res. 68 (2008) 6851-6858. doi:10.1158/0008-5472.CAN-08-0718.

[7] E. Camerer, A.A. Qazi, D.N. Duong, I. Cornelissen, R. Advincula, S.R. Coughlin, Platelets, protease-activated receptors, and fibrinogen in hematogenous metastasis, Blood. 104 (2004) 397-401. doi:10.1182/blood-2004-02-0434.

[8] N.M. Bambace, C.E. Holmes, The platelet contribution to cancer progression, J. Thromb. Haemost. JTH. 9 (2011) 237-249. doi:10.1111/j.1538-7836.2010.04131.x.

[9] A.A. Khorana, C.W. Francis, E. Culakova, N.M. Kuderer, G.H. Lyman, Thromboembolism is a leading cause of death in cancer patients receiving outpatient chemotherapy, J. Thromb. Haemost. JTH. 5 (2007) 632-634. doi:10.1111/j.15387836.2007.02374.x.

[10] J. Levin, C.L. Conley, THROMBOCYTOSIS ASSOCIATED WITH MALIGNANT DISEASE, Arch. Intern. Med. 114 (1964) 497-500.

[11] E. Heinmöller, T. Schropp, O. Kisker, B. Simon, R. Seitz, R.J. Weinel, Tumor cellinduced platelet aggregation in vitro by human pancreatic cancer cell lines, Scand. J. Gastroenterol. 30 (1995) 1008-1016.

[12] E. Heinmöller, R.J. Weinel, H.H. Heidtmann, U. Salge, R. Seitz, I. Schmitz, et al., Studies on tumor-cell-induced platelet aggregation in human lung cancer cell lines, J. Cancer Res. Clin. Oncol. 122 (1996) 735-744.

[13] E. Pearlstein, P.L. Salk, G. Yogeeswaran, S. Karpatkin, Correlation between spontaneous metastatic potential, platelet-aggregating activity of cell surface extracts, 
and cell surface sialylation in 10 metastatic-variant derivatives of a rat renal sarcoma cell line, Proc. Natl. Acad. Sci. U. S. A. 77 (1980) 4336-4339.

[14] S. Karpatkin, C. Ambrogio, E. Pearlstein, The role of tumor-induced platelet aggregation, platelet adhesion and adhesive proteins in tumor metastasis, Prog. Clin. Biol. Res. 283 (1988) 585-606.

[15] E. Bastida, A. Ordinas, G.A. Jamieson, Differing platelet aggregating effects by two tumor cell lines: absence of role for platelet-derived ADP, Am. J. Hematol. 11 (1981) 367-378.

[16] M.L. Nierodzik, A. Plotkin, F. Kajumo, S. Karpatkin, Thrombin stimulates tumorplatelet adhesion in vitro and metastasis in vivo, J. Clin. Invest. 87 (1991) 229-236. doi:10.1172/JCI114976.

[17] L. Traby, A. Kaider, R. Schmid, A. Kranz, P. Quehenberger, P.A. Kyrle, et al., The effects of low-molecular-weight heparin at two different dosages on thrombin generation in cancer patients. A randomised controlled trial, Thromb. Haemost. 104 (2010) 92-99. doi:10.1160/TH09-12-0863.

[18] D. Alonso-Escolano, A.Y. Strongin, A.W. Chung, E.I. Deryugina, M.W. Radomski, Membrane type-1 matrix metalloproteinase stimulates tumour cell-induced platelet aggregation: role of receptor glycoproteins, Br. J. Pharmacol. 141 (2004) 241-252. doi:10.1038/sj.bjp.0705606.

[19] P. Jurasz, M.W. Stewart, A. Radomski, F. Khadour, M. Duszyk, M.W. Radomski, Role of von Willebrand factor in tumour cell-induced platelet aggregation: differential regulation by NO and prostacyclin, Br. J. Pharmacol. 134 (2001) 1104-1112. doi:10.1038/sj.bjp.0704343.

[20] X. de Leval, V. Benoit, J. Delarge, F. Julémont, B. Masereel, B. Pirotte, et al., Pharmacological evaluation of the novel thromboxane modulator BM-567 (II/II). Effects of BM-567 on osteogenic sarcoma-cell-induced platelet aggregation, Prostaglandins Leukot. Essent. Fatty Acids. 68 (2003) 55-59.

[21] M.D. Sternlicht, Z. Werb, How matrix metalloproteinases regulate cell behavior, Annu. Rev. Cell Dev. Biol. 17 (2001) 463-516. doi:10.1146/annurev.cellbio.17.1.463.

[22] H.-M. Ko, Y.-M. Park, B. Jung, H.-A. Kim, J.-H. Choi, S.J. Park, et al., Involvement of matrix metalloproteinase-9 in platelet-activating factor-induced angiogenesis, FEBS Lett. 579 (2005) 2369-2375. doi:10.1016/j.febslet.2005.03.035.

[23] P. Jurasz, S. North, P. Venner, M.W. Radomski, Matrix metalloproteinase-2 contributes to increased platelet reactivity in patients with metastatic prostate cancer: a preliminary study, Thromb. Res. $112 \quad$ (2003) 59-64. doi:10.1016/j.thromres.2003.10.012. 
[24] W. Ruf, N. Yokota, F. Schaffner, Tissue factor in cancer progression and angiogenesis, Thromb. Res. 125 Suppl 2 (2010) S36-38. doi:10.1016/S00493848(10)70010-4.

[25] J.S. Palumbo, K.E. Talmage, J.V. Massari, C.M. La Jeunesse, M.J. Flick, K.W. Kombrinck, et al., Platelets and fibrin(ogen) increase metastatic potential by impeding natural killer cell-mediated elimination of tumor cells, Blood. 105 (2005) 178-185. doi:10.1182/blood-2004-06-2272.

[26] E. Pearlstein, C. Ambrogio, G. Gasic, S. Karpatkin, Inhibition of the plateletaggregating activity of two human adenocarcinomas of the colon and an anaplastic murine tumor with a specific thrombin inhibitor: dansylarginine N-(3-ethyl-1, 5pentanediyl)amide, Prog. Clin. Biol. Res. 89 (1982) 479-502.

[27] M.T. Nieman, G. LaRusch, C. Fang, Y. Zhou, A.H. Schmaier, Oral thrombostatin FM19 inhibits prostate cancer, Thromb. Haemost. 104 (2010) 1044-1048. doi:10.1160/TH09-08-0570.

[28] P. Mehta, D. Lawson, M.B. Ward, L. Lee-Ambrose, A. Kimura, Effects of thromboxane A2 inhibition on osteogenic sarcoma cell-induced platelet aggregation, Cancer Res. 46 (1986) 5061-5063.

[29] S. Gebremeskel, T. LeVatte, R.S. Liwski, B. Johnston, M. Bezuhly, The reversible P2Y12 inhibitor ticagrelor inhibits metastasis and improves survival in mouse models of cancer, Int. J. Cancer J. Int. Cancer. 136 (2015) 234-240. doi:10.1002/ijc.28947.

[30] S. Mezouar, R. Darbousset, F. Dignat-George, L. Panicot-Dubois, C. Dubois, Inhibition of platelet activation prevents the P-selectin and integrin-dependent accumulation of cancer cell microparticles and reduces tumor growth and metastasis in vivo, Int. J. Cancer J. Int. Cancer. 136 (2015) 462-475. doi:10.1002/ijc.28997.

[31] O. Uluçkan, M.C. Eagleton, D.H. Floyd, E.A. Morgan, A.C. Hirbe, M. Kramer, et al., APT102, a novel adpase, cooperates with aspirin to disrupt bone metastasis in mice, J. Cell. Biochem. 104 (2008) 1311-1323. doi:10.1002/jcb.21709.

[32] M.C.M. Mah-Becherel, J. Céraline, G. Deplanque, M.-P. Chenard, J.-P. Bergerat, J.-P. Cazenave, et al., Anti-angiogenic effects of the thienopyridine SR 25989 in vitro and in vivo in a murine pulmonary metastasis model, Br. J. Cancer. 86 (2002) 803-810. doi:10.1038/sj.bjc.6600142.

[33] H. Bando, T. Yamashita, E. Tsubura, Effects of antiplatelet agents on pulmonary metastases, Gan. 75 (1984) 284-291.

[34] E. Bastida, G. Escolar, L. Almirall, A. Ordinas, Platelet activation induced by a human neuroblastoma tumor cell line is reduced by prior administration of ticlopidine, Thromb. Haemost. 55 (1986) 333-337. 
[35] L. Lian, W. Li, Z.-Y. Li, Y.-X. Mao, Y.-T. Zhang, Y.-M. Zhao, et al., Inhibition of MCF-7 breast cancer cell-induced platelet aggregation using a combination of antiplatelet drugs, Oncol. Lett. 5 (2013) 675-680. doi:10.3892/ol.2012.1074.

[36] N.M. Bambace, J.E. Levis, C.E. Holmes, The effect of P2Y-mediated platelet activation on the release of VEGF and endostatin from platelets, Platelets. 21 (2010) 8593. doi:10.3109/09537100903470298.

[37] J.A. Coppinger, R. O'Connor, K. Wynne, M. Flanagan, M. Sullivan, P.B. Maguire, et al., Moderation of the platelet releasate response by aspirin, Blood. 109 (2007) 47864792. doi:10.1182/blood-2006-07-038539.

[38] F. Ogawa, H. Amano, Y. Ito, Y. Matsui, K. Hosono, H. Kitasato, et al., Aspirin reduces lung cancer metastasis to regional lymph nodes, Biomed. Pharmacother. Bioméd. Pharmacothérapie. 68 (2014) 79-86. doi:10.1016/j.biopha.2013.11.006.

[39] C. Medina, S. Harmon, I. Inkielewicz, M.J. Santos-Martinez, M. Jones, P. Cantwell, et al., Differential inhibition of tumour cell-induced platelet aggregation by the nicotinate aspirin prodrug (ST0702) and aspirin, Br. J. Pharmacol. 166 (2012) 938-949. doi:10.1111/j.1476-5381.2011.01794.x.

[40] G. Sitia, R. Aiolfi, P. Di Lucia, M. Mainetti, A. Fiocchi, F. Mingozzi, et al., Antiplatelet therapy prevents hepatocellular carcinoma and improves survival in a mouse model of chronic hepatitis B, Proc. Natl. Acad. Sci. U. S. A. 109 (2012) E2165-2172. doi:10.1073/pnas.1209182109.

[41] E.M. Battinelli, B.A. Markens, J.E. Italiano, Release of angiogenesis regulatory proteins from platelet alpha granules: modulation of physiologic and pathologic angiogenesis, Blood. 118 (2011) 1359-1369. doi:10.1182/blood-2011-02-334524.

[42] N.M. Vad, S.K. Kudugunti, H. Wang, G.J. Bhat, M.Y. Moridani, Efficacy of acetylsalicylic acid (aspirin) in skin B16-F0 melanoma tumor-bearing C57BL/6 mice, Tumour Biol. J. Int. Soc. Oncodevelopmental Biol. Med. 35 (2014) 4967-4976. doi:10.1007/s13277-014-1654-1.

[43] O. Arrieta, P. Guevara, S. Reyes, G. Palencia, E. Rivera, J. Sotelo, Paradoxical effect of aspirin on the growth of $\mathrm{C} 6$ rat glioma and on time of development of ENU-induced tumors of the nervous system, J. Cancer Res. Clin. Oncol. 127 (2001) 681-686.

[44] S. Mezouar, R. Darbousset, F. Dignat-George, L. Panicot-Dubois, C. Dubois, Inhibition of platelet activation prevents the P-selectin and integrin-dependent accumulation of cancer cell microparticles and reduces tumor growth and metastasis in vivo, Int. J. Cancer J. Int. Cancer. 136 (2015) 462-475. doi:10.1002/ijc.28997.

[45] D. Alonso-Escolano, A.Y. Strongin, A.W. Chung, E.I. Deryugina, M.W. Radomski, Membrane type-1 matrix metalloproteinase stimulates tumour cell-induced platelet aggregation: role of receptor glycoproteins, Br. J. Pharmacol. 141 (2004) 241-252. 
doi:10.1038/sj.bjp.0705606.

[46] L. Lian, W. Li, Z.-Y. Li, Y.-X. Mao, Y.-T. Zhang, Y.-M. Zhao, et al., Inhibition of MCF-7 breast cancer cell-induced platelet aggregation using a combination of antiplatelet drugs, Oncol. Lett. 5 (2013) 675-680. doi:10.3892/ol.2012.1074.

[47] R.L. Stone, A.M. Nick, I.A. McNeish, F. Balkwill, H.D. Han, J. Bottsford-Miller, et al., Paraneoplastic thrombocytosis in ovarian cancer, N. Engl. J. Med. 366 (2012) 610-618. doi:10.1056/NEJMoa1110352.

[48] M. Yan, P. Jurasz, The role of platelets in the tumor microenvironment: From solid tumors to leukemia, Biochim. Biophys. Acta. (2015). doi:10.1016/j.bbamcr.2015.07.008.

[49] R. Li, M. Ren, N. Chen, M. Luo, X. Deng, J. Xia, et al., Presence of intratumoral platelets is associated with tumor vessel structure and metastasis, BMC Cancer. 14 (2014) 167. doi:10.1186/1471-2407-14-167.

[50] U. Rodeck, M. Herlyn, Growth factors in melanoma, Cancer Metastasis Rev. 10 (1991) 89-101.

[51] H. Yu, T. Rohan, Role of the insulin-like growth factor family in cancer development and progression, J. Natl. Cancer Inst. 92 (2000) 1472-1489.

[52] D.J. Hicklin, L.M. Ellis, Role of the vascular endothelial growth factor pathway in tumor growth and angiogenesis, J. Clin. Oncol. Off. J. Am. Soc. Clin. Oncol. 23 (2005) 1011-1027. doi:10.1200/JC0.2005.06.081.

[53] C.L. Arteaga, T.D. Brown, J.G. Kuhn, H.S. Shen, T.J. O’Rourke, K. Beougher, et al., Phase I clinical and pharmacokinetic trial of Brequinar sodium (DuP 785; NSC 368390), Cancer Res. 49 (1989) 4648-4653.

[54] M. Pollak, M.J. Blouin, J.C. Zhang, J.J. Kopchick, Reduced mammary gland carcinogenesis in transgenic mice expressing a growth hormone antagonist, $\mathrm{Br}$. J. Cancer. 85 (2001) 428-430. doi:10.1054/bjoc.2001.1895.

[55] K.E. Friend, Cancer and the potential place for growth hormone receptor antagonist therapy, Growth Horm. IGF Res. Off. J. Growth Horm. Res. Soc. Int. IGF Res. Soc. 11 Suppl A (2001) S121-123.

[56] S.P. Dineen, C.L. Roland, J.E. Toombs, M. Kelher, C.C. Silliman, R.A. Brekken, et al., The acellular fraction of stored platelets promotes tumor cell invasion, J. Surg. Res. 153 (2009) 132-137. doi:10.1016/j.jss.2008.04.013.

[57] B. Sloan, N.S. Scheinfeld, Pazopanib, a VEGF receptor tyrosine kinase inhibitor for cancer therapy, Curr. Opin. Investig. Drugs Lond. Engl. 2000. 9 (2008) 1324-1335.

[58] J.M. Wood, G. Bold, E. Buchdunger, R. Cozens, S. Ferrari, J. Frei, et al., PTK787/ZK 222584, a novel and potent inhibitor of vascular endothelial growth factor receptor 
tyrosine kinases, impairs vascular endothelial growth factor-induced responses and tumor growth after oral administration, Cancer Res. 60 (2000) 2178-2189.

[59] O. Potapova, A.D. Laird, M.A. Nannini, A. Barone, G. Li, K.G. Moss, et al., Contribution of individual targets to the antitumor efficacy of the multitargeted receptor tyrosine kinase inhibitor SU11248, Mol. Cancer Ther. 5 (2006) 1280-1289. doi:10.1158/1535-7163.MCT-03-0156.

[60] C.L. Arteaga, S.D. Hurd, A.R. Winnier, M.D. Johnson, B.M. Fendly, J.T. Forbes, Antitransforming growth factor (TGF)-beta antibodies inhibit breast cancer cell tumorigenicity and increase mouse spleen natural killer cell activity. Implications for a possible role of tumor cell/host TGF-beta interactions in human breast cancer progression, J. Clin. Invest. 92 (1993) 2569-2576. doi:10.1172/JCI116871.

[61] S.J. Kim, H. Uehara, S. Yazici, R.R. Langley, J. He, R. Tsan, et al., Simultaneous blockade of platelet-derived growth factor-receptor and epidermal growth factorreceptor signaling and systemic administration of paclitaxel as therapy for human prostate cancer metastasis in bone of nude mice, Cancer Res. 64 (2004) 4201-4208. doi:10.1158/0008-5472.CAN-03-3763.

[62] X. Jiang, C.M. Dutton, W. ning Qi, J.A. Block, P. Brodt, M. Durko, et al., Inhibition of MMP-1 expression by antisense RNA decreases invasiveness of human chondrosarcoma, J. Orthop. Res. Off. Publ. Orthop. Res. Soc. 21 (2003) 1063-1070. doi:10.1016/S07360266(03)00079-2.

[63] M. Balbín, A. Fueyo, A.M. Tester, A.M. Pendás, A.S. Pitiot, A. Astudillo, et al., Loss of collagenase-2 confers increased skin tumor susceptibility to male mice, Nat. Genet. 35 (2003) 252-257. doi:10.1038/ng1249.

[64] T. Itoh, M. Tanioka, H. Yoshida, T. Yoshioka, H. Nishimoto, S. Itohara, Reduced angiogenesis and tumor progression in gelatinase A-deficient mice, Cancer Res. 58 (1998) 1048-1051.

[65] H.B. Acuff, K.J. Carter, B. Fingleton, D.L. Gorden, L.M. Matrisian, Matrix metalloproteinase- 9 from bone marrow-derived cells contributes to survival but not growth of tumor cells in the lung microenvironment, Cancer Res. 66 (2006) 259-266. doi:10.1158/0008-5472.CAN-05-2502.

[66] J.-M. Kim, E.-M. Noh, K.-B. Kwon, J.-S. Kim, Y.-O. You, J.-K. Hwang, et al., Suppression of TPA-induced tumor cell invasion by sulfuretin via inhibition of NF- $\mathrm{B}$ dependent MMP-9 expression, Oncol. Rep. 29 (2013) 1231-1237. doi:10.3892/or.2012.2218.

[67] L. Devy, L. Huang, L. Naa, N. Yanamandra, H. Pieters, N. Frans, et al., Selective inhibition of matrix metalloproteinase-14 blocks tumor growth, invasion, and angiogenesis, Cancer Res. 69 (2009) 1517-1526. doi:10.1158/0008-5472.CAN-08-3255. 
[68] E.I. Deryugina, J.P. Quigley, Matrix metalloproteinases and tumor metastasis, Cancer Metastasis Rev. 25 (2006) 9-34. doi:10.1007/s10555-006-7886-9.

[69] T.N. Mitropoulou, G.N. Tzanakakis, D. Kletsas, H.P. Kalofonos, N.K. Karamanos, Letrozole as a potent inhibitor of cell proliferation and expression of metalloproteinases (MMP-2 and MMP-9) by human epithelial breast cancer cells, Int. J. Cancer J. Int. Cancer. 104 (2003) 155-160. doi:10.1002/ijc.10941.

[70] F. Xu, Z.-G. Ou-Yang, S.-H. Zhang, D.-Q. Song, R.-G. Shao, Y.-S. Zhen, Sodium caffeate induces endothelial cell apoptosis and inhibits VEGF expression in cancer cells, Yao Xue Xue Bao. 41 (2006) 572-576.

[71] S. Massberg, I. Konrad, K. Schürzinger, M. Lorenz, S. Schneider, D. Zohlnhoefer, et al., Platelets secrete stromal cell-derived factor 1alpha and recruit bone marrow-derived progenitor cells to arterial thrombi in vivo, J. Exp. Med. 203 (2006) 1221-1233. doi:10.1084/jem.20051772.

[72] B.A. Teicher, S.P. Fricker, CXCL12 (SDF-1)/CXCR4 pathway in cancer, Clin. Cancer Res. Off. J. Am. Assoc. Cancer Res. 16 (2010) 2927-2931. doi:10.1158/1078-0432.CCR09-2329.

[73] M.S. Cho, J. Bottsford-Miller, H.G. Vasquez, R. Stone, B. Zand, M.H. Kroll, et al., Platelets increase the proliferation of ovarian cancer cells, Blood. 120 (2012) 48694872. doi:10.1182/blood-2012-06-438598.

[74] Z. Wang, H. Huang, Platelet factor-4 (CXCL4/PF-4): an angiostatic chemokine for cancer therapy, Cancer Lett. 331 (2013) 147-153. doi:10.1016/j.canlet.2013.01.006.

[75] G.M. Ibele, N.E. Kay, G.J. Johnson, H.S. Jacob, Human platelets exert cytotoxic effects on tumor cells, Blood. 65 (1985) 1252-1255.

[76] M. Trikha, Z. Zhou, J. Timar, E. Raso, M. Kennel, E. Emmell, et al., Multiple roles for platelet GPIIb/IIIa and alphavbeta3 integrins in tumor growth, angiogenesis, and metastasis, Cancer Res. 62 (2002) 2824-2833.

[77] J. Folkman, E. Merler, C. Abernathy, G. Williams, Isolation of a tumor factor responsible for angiogenesis, J. Exp. Med. 133 (1971) 275-288.

[78] N. Nishida, H. Yano, T. Nishida, T. Kamura, M. Kojiro, Angiogenesis in cancer, Vasc. Health Risk Manag. 2 (2006) 213-219.

[79] P. Jurasz, D. Alonso-Escolano, M.W. Radomski, Platelet--cancer interactions: mechanisms and pharmacology of tumour cell-induced platelet aggregation, $\mathrm{Br}$. J. Pharmacol. 143 (2004) 819-826. doi:10.1038/sj.bjp.0706013.

[80] S. Sabrkhany, A.W. Griffioen, M.G.A. Oude Egbrink, The role of blood platelets in tumor angiogenesis, Biochim. Biophys. Acta. 1815 (2011) 189-196. 
doi:10.1016/j.bbcan.2010.12.001.

[81] E. Pipili-Synetos, E. Papadimitriou, M.E. Maragoudakis, Evidence that platelets promote tube formation by endothelial cells on matrigel, Br. J. Pharmacol. 125 (1998) 1252-1257. doi:10.1038/sj.bjp.0702191.

[82] A. Brill, O. Dashevsky, J. Rivo, Y. Gozal, D. Varon, Platelet-derived microparticles induce angiogenesis and stimulate post-ischemic revascularization, Cardiovasc. Res. 67 (2005) 30-38. doi:10.1016/j.cardiores.2005.04.007.

[83] A. Brill, H. Elinav, D. Varon, Differential role of platelet granular mediators in angiogenesis, Cardiovasc. Res. 63 (2004) 226-235. doi:10.1016/j.cardiores.2004.04.012.

[84] J. Kisucka, C.E. Butterfield, D.G. Duda, S.C. Eichenberger, S. Saffaripour, J. Ware, et al., Platelets and platelet adhesion support angiogenesis while preventing excessive hemorrhage, Proc. Natl. Acad. Sci. U. S. A. 103 (2006) 855-860. doi:10.1073/pnas.0510412103.

[85] C. Kut, F. Mac Gabhann, A.S. Popel, Where is VEGF in the body? A meta-analysis of VEGF distribution in cancer, Br. J. Cancer. 97 (2007) 978-985. doi:10.1038/sj.bjc.6603923.

[86] W. Jelkmann, Pitfalls in the measurement of circulating vascular endothelial growth factor, Clin. Chem. 47 (2001) 617-623.

[87] D. Buergy, F. Wenz, C. Groden, M.A. Brockmann, Tumor-platelet interaction in solid tumors, Int. J. Cancer J. Int. Cancer. 130 (2012) 2747-2760. doi:10.1002/ijc.27441.

[88] A. Zaslavsky, K.-H. Baek, R.C. Lynch, S. Short, J. Grillo, J. Folkman, et al., Plateletderived thrombospondin-1 is a critical negative regulator and potential biomarker of angiogenesis, Blood. 115 (2010) 4605-4613. doi:10.1182/blood-2009-09-242065.

[89] J.E. Italiano, J.L. Richardson, S. Patel-Hett, E. Battinelli, A. Zaslavsky, S. Short, et al., Angiogenesis is regulated by a novel mechanism: pro- and antiangiogenic proteins are organized into separate platelet alpha granules and differentially released, Blood. 111 (2008) 1227-1233. doi:10.1182/blood-2007-09-113837.

[90] A.F. Chambers, A.C. Groom, I.C. MacDonald, Dissemination and growth of cancer cells in metastatic sites, Nat. Rev. Cancer. 2 (2002) 563-572. doi:10.1038/nrc865.

[91] I.J. Fidler, Metastasis: guantitative analysis of distribution and fate of tumor embolilabeled with 125 I-5-iodo-2'-deoxyuridine, J. Natl. Cancer Inst. 45 (1970) 773782.

[92] H. Shau, M.D. Roth, S.H. Golub, Regulation of natural killer function by nonlymphoid cells, Nat. Immun. 12 (1993) 235-249.

[93] S. Jain, S. Russell, J. Ware, Platelet glycoprotein VI facilitates experimental lung 
metastasis in syngenic mouse models, J. Thromb. Haemost. JTH. 7 (2009) 1713-1717. doi:10.1111/j.1538-7836.2009.03559.x.

[94] L. Erpenbeck, M.P. Schön, Deadly allies: the fatal interplay between platelets and metastasizing cancer cells, Blood. 115 (2010) 3427-3436. doi:10.1182/blood-2009-10247296.

[95] H. Läubli, L. Borsig, Selectins promote tumor metastasis, Semin. Cancer Biol. 20 (2010) 169-177. doi:10.1016/j.semcancer.2010.04.005.

[96] R.M. Nelson, O. Cecconi, W.G. Roberts, A. Aruffo, R.J. Linhardt, M.P. Bevilacqua, Heparin oligosaccharides bind L- and P-selectin and inhibit acute inflammation, Blood. 82 (1993) 3253-3258.

[97] N.M. Varki, A. Varki, Heparin inhibition of selectin-mediated interactions during the hematogenous phase of carcinoma metastasis: rationale for clinical studies in humans, Semin. Thromb. Hemost. 28 (2002) 53-66. doi:10.1055/s-2002-20564.

[98] L. Borsig, R. Wong, J. Feramisco, D.R. Nadeau, N.M. Varki, A. Varki, Heparin and cancer revisited: mechanistic connections involving platelets, P-selectin, carcinoma mucins, and tumor metastasis, Proc. Natl. Acad. Sci. U. S. A. 98 (2001) 3352-3357. doi:10.1073/pnas.061615598.

[99] M.M. Fuster, J.R. Brown, L. Wang, J.D. Esko, A disaccharide precursor of sialyl Lewis X inhibits metastatic potential of tumor cells, Cancer Res. 63 (2003) 2775-2781.

[100] L. Borsig, R. Wong, R.O. Hynes, N.M. Varki, A. Varki, Synergistic effects of L- and Pselectin in facilitating tumor metastasis can involve non-mucin ligands and implicate leukocytes as enhancers of metastasis, Proc. Natl. Acad. Sci. U. S. A. 99 (2002) 21932198. doi:10.1073/pnas.261704098.

[101] J.P. Stone, D.D. Wagner, P-selectin mediates adhesion of platelets to neuroblastoma and small cell lung cancer, J. Clin. Invest. 92 (1993) 804-813. doi:10.1172/JCI116654.

[102] Y.J. Kim, L. Borsig, N.M. Varki, A. Varki, P-selectin deficiency attenuates tumor growth and metastasis, Proc. Natl. Acad. Sci. U. S. A. 95 (1998) 9325-9330.

[103] H. Läubli, L. Borsig, Selectins as mediators of lung metastasis, Cancer Microenviron. Off. J. Int. Cancer Microenviron. Soc. 3 (2010) 97-105. doi:10.1007/s12307-010-0043-6.

[104] G. Mannori, P. Crottet, O. Cecconi, K. Hanasaki, A. Aruffo, R.M. Nelson, et al., Differential colon cancer cell adhesion to E-, P-, and L-selectin: role of mucin-type glycoproteins, Cancer Res. 55 (1995) 4425-4431.

[105] E.O. Kozlowski, M.S.G. Pavao, L. Borsig, Ascidian dermatan sulfates attenuate 
metastasis, inflammation and thrombosis by inhibition of P-selectin, J. Thromb. Haemost. JTH. 9 (2011) 1807-1815. doi:10.1111/j.1538-7836.2011.04401.x.

[106] S. Karpatkin, E. Pearlstein, C. Ambrogio, B.S. Coller, Role of adhesive proteins in platelet tumor interaction in vitro and metastasis formation in vivo, J. Clin. Invest. 81 (1988) 1012-1019. doi:10.1172/JCI113411.

[107] W. Zhang, S. Dang, T. Hong, J. Tang, J. Fan, D. Bu, et al., A humanized single-chain antibody against beta 3 integrin inhibits pulmonary metastasis by preferentially fragmenting activated platelets in the tumor microenvironment, Blood. 120 (2012) 2889-2898. doi:10.1182/blood-2012-04-425207.

[108] S.J. Bakewell, P. Nestor, S. Prasad, M.H. Tomasson, N. Dowland, M. Mehrotra, et al., Platelet and osteoclast beta3 integrins are critical for bone metastasis, Proc. Natl. Acad. Sci. U. S. A. 100 (2003) 14205-14210. doi:10.1073/pnas.2234372100.

[109] H. Kitagawa, N. Yamamoto, K. Yamamoto, K. Tanoue, G. Kosaki, H. Yamazaki, Involvement of platelet membrane glycoprotein Ib and glycoprotein IIb/IIIa complex in thrombin-dependent and -independent platelet aggregations induced by tumor cells, Cancer Res. 49 (1989) 537-541.

[110] A. Amirkhosravi, S.A. Mousa, M. Amaya, S. Blaydes, H. Desai, T. Meyer, et al., Inhibition of tumor cell-induced platelet aggregation and lung metastasis by the oral GpIIb/IIIa antagonist XV454, Thromb. Haemost. 90 (2003) 549-554. doi:10.1267/THR003030549.

[111] A. Boucharaba, C.-M. Serre, S. Grès, J.S. Saulnier-Blache, J.-C. Bordet, J. Guglielmi, et al., Platelet-derived lysophosphatidic acid supports the progression of osteolytic bone metastases in breast cancer, J. Clin. Invest. 114 (2004) 1714-1725. doi:10.1172/JCI22123.

[112] L. Erpenbeck, B. Nieswandt, M. Schön, M. Pozgajova, M.P. Schön, Inhibition of platelet GPIb alpha and promotion of melanoma metastasis, J. Invest. Dermatol. 130 (2010) 576-586. doi:10.1038/jid.2009.278.

[113] S. Jain, M. Zuka, J. Liu, S. Russell, J. Dent, J.A. Guerrero, et al., Platelet glycoprotein Ib alpha supports experimental lung metastasis, Proc. Natl. Acad. Sci. U. S. A. 104 (2007) 9024-9028. doi:10.1073/pnas.0700625104.

[114] P.S. Steeg, New insights into the tumor metastatic process revealed by gene expression profiling, Am. J. Pathol. 166 (2005) 1291-1294. doi:10.1016/S00029440(10)62348-6.

[115] B.A. Kerr, N.P. McCabe, W. Feng, T.V. Byzova, Platelets govern pre-metastatic tumor communication to bone, Oncogene. $32 \quad$ (2013) 4319-4324. doi:10.1038/onc.2012.447. 
[116] M. Labelle, S. Begum, R.O. Hynes, Platelets guide the formation of early metastatic niches, Proc. Natl. Acad. Sci. U. S. A. 111 (2014) E3053-3061. doi:10.1073/pnas.1411082111.

[117] A. Palumbo, A. Bertola, P. Musto, T. Caravita, V. Callea, M. Nunzi, et al., Oral melphalan, prednisone, and thalidomide for newly diagnosed patients with myeloma, Cancer. 104 (2005) 1428-1433. doi:10.1002/cncr.21342.

[118] W.J. Storkus, J.R. Dawson, Target structures involved in natural killing (NK): characteristics, distribution, and candidate molecules, Crit. Rev. Immunol. 10 (1991) 393-416.

[119] N. Hanna, The role of natural killer cells in the control of tumor growth and metastasis, Biochim. Biophys. Acta. 780 (1985) 213-226.

[120] B. Nieswandt, M. Hafner, B. Echtenacher, D.N. Männel, Lysis of tumor cells by natural killer cells in mice is impeded by platelets, Cancer Res. 59 (1999) 1295-1300.

[121] K. Palucka, J. Banchereau, Cancer immunotherapy via dendritic cells, Nat. Rev. Cancer. 12 (2012) 265-277. doi:10.1038/nrc3258.

[122] K. Imai, S. Matsuyama, S. Miyake, K. Suga, K. Nakachi, Natural cytotoxic activity of peripheral-blood lymphocytes and cancer incidence: an 11-year follow-up study of a general population, Lancet. 356 (2000) 1795-1799. doi:10.1016/S01406736(00)03231-1.

[123] T. Placke, M. Örgel, M. Schaller, G. Jung, H.-G. Rammensee, H.-G. Kopp, et al., Platelet-derived MHC class I confers a pseudonormal phenotype to cancer cells that subverts the antitumor reactivity of natural killer immune cells, Cancer Res. 72 (2012) 440-448. doi:10.1158/0008-5472.CAN-11-1872.

[124] J. Tímár, J. Tóvári, E. Rásó, L. Mészáros, B. Bereczky, K. Lapis, Platelet-mimicry of cancer cells: epiphenomenon with clinical significance, Oncology. 69 (2005) 185-201. doi:10.1159/000088069.

[125] C.L. Chaffer, R.A. Weinberg, A perspective on cancer cell metastasis, Science. 331 (2011) 1559-1564. doi:10.1126/science.1203543.

[126] D. Sharma, K.E. Brummel-Ziedins, B.A. Bouchard, C.E. Holmes, Platelets in tumor progression: a host factor that offers multiple potential targets in the treatment of cancer, J. Cell. Physiol. 229 (2014) 1005-1015. doi:10.1002/jcp.24539.

[127] S.J. Shattil, C. Kim, M.H. Ginsberg, The final steps of integrin activation: the end game, Nat. Rev. Mol. Cell Biol. 11 (2010) 288-300. doi:10.1038/nrm2871.

[128] J.S. Desgrosellier, D.A. Cheresh, Integrins in cancer: biological implications and therapeutic opportunities, Nat. Rev. Cancer. 10 (2010) 9-22. doi:10.1038/nrc2748. 
[129] A. Klepfish, M.A. Greco, S. Karpatkin, Thrombin stimulates melanoma tumor-cell binding to endothelial cells and subendothelial matrix, Int. J. Cancer J. Int. Cancer. 53 (1993) 978-982.

[130] C.L. Hall, C.W. Dubyk, T.A. Riesenberger, D. Shein, E.T. Keller, K.L. van Golen, Type I collagen receptor (alpha2beta1) signaling promotes prostate cancer invasion through RhoC GTPase, Neoplasia N. Y. N. 10 (2008) 797-803.

[131] D. Schumacher, B. Strilic, K.K. Sivaraj, N. Wettschureck, S. Offermanns, Plateletderived nucleotides promote tumor-cell transendothelial migration and metastasis via P2Y2 receptor, Cancer Cell. 24 (2013) 130-137. doi:10.1016/j.ccr.2013.05.008.

[132] G. Skolnik, U. Bagge, A. Dahlström, H. Ahlman, The importance of 5-HT for tumor cell lodgement in the liver, Int. J. Cancer J. Int. Cancer. 33 (1984) 519-523.

[133] M.H. Sarker, D.-E. Hu, P.A. Fraser, Regulation of cerebromicrovascular permeability by lysophosphatidic acid, Microcirc. N. Y. N 1994.17 (2010) 39-46. doi:10.1111/j.1549-8719.2010.00001.x.

[134] M. Umezu-Goto, J. Tanyi, J. Lahad, S. Liu, S. Yu, R. Lapushin, et al., Lysophosphatidic acid production and action: validated targets in cancer?, J. Cell. Biochem. 92 (2004) 1115-1140. doi:10.1002/jcb.20113.

[135] W.H. Moolenaar, Development of our current understanding of bioactive lysophospholipids, Ann. N. Y. Acad. Sci. 905 (2000) 1-10.

[136] A. Boucharaba, C.-M. Serre, S. Grès, J.S. Saulnier-Blache, J.-C. Bordet, J. Guglielmi, et al., Platelet-derived lysophosphatidic acid supports the progression of osteolytic bone metastases in breast cancer, J. Clin. Invest. 114 (2004) 1714-1725. doi:10.1172/JCI22123.

[137] M. Rolli, E. Fransvea, J. Pilch, A. Saven, B. Felding-Habermann, Activated integrin alphavbeta3 cooperates with metalloproteinase MMP-9 in regulating migration of metastatic breast cancer cells, Proc. Natl. Acad. Sci. U. S. A. 100 (2003) 9482-9487. doi:10.1073/pnas.1633689100.

[138] C. Anderberg, S.I. Cunha, Z. Zhai, E. Cortez, E. Pardali, J.R. Johnson, et al., Deficiency for endoglin in tumor vasculature weakens the endothelial barrier to metastatic dissemination, J. Exp. Med. 210 (2013) 563-579. doi:10.1084/jem.20120662.

[139] W.F. Sindelar, T.S. Tralka, A.S. Ketcham, Electron microscopic observations on formation of pulmonary metastases, J. Surg. Res. 18 (1975) 137-161.

[140] R.M. Hoffman, Green fluorescent protein to visualize cancer progression and metastasis, Methods Enzymol. 302 (1999) 20-31.

[141] A. Yamamoto, S. Yano, M. Shiraga, H. Ogawa, H. Goto, T. Miki, et al., A third- 
generation matrix metalloproteinase (MMP) inhibitor (ONO-4817) combined with docetaxel suppresses progression of lung micrometastasis of MMP-expressing tumor cells in nude mice, Int. J. Cancer J. Int. Cancer. 103 (2003) 822-828. doi:10.1002/ijc.10875.

[142] B.L. Tranum, A. Haut, Thrombocytosis: platelet kinetics in neoplasia, J. Lab. Clin. Med. 84 (1974) 615-619.

[143] R.J. Lin, V. Afshar-Kharghan, A.I. Schafer, Paraneoplastic thrombocytosis: the secrets of tumor self-promotion, Blood. 124 (2014) 184-187. doi:10.1182/blood-201403-562538.

[144] J.P. Ferriere, D. Bernard, M. Legros, J. Chassagne, P. Chollet, G. Gaillard, et al., betaThromboglobulin in patients with breast cancer, Am. J. Hematol. 19 (1985) 47-53.

[145] T. Yazaki, H. Inage, T. Iizumi, A. Koyama, S. Kanoh, K. Koiso, et al., Studies on platelet function in patients with prostatic cancer. Preliminary report, Urology. 30 (1987) 60-63.

[146] M. Mantur, H. Kemona, R. Kozłowski, I. Kemona-Chetnik, Effect of tumor stage and nephrectomy on CD62P expression and sP-selectin concentration in renal cancer, Neoplasma. 50 (2003) 262-265.

[147] F. Tas, D. Duranyildiz, H.O. Soydinc, I. Cicin, M. Selam, K. Uygun, et al., Effect of maximum-tolerated doses and low-dose metronomic chemotherapy on serum vascular endothelial growth factor and thrombospondin-1 levels in patients with advanced nonsmall cell lung cancer, Cancer Chemother. Pharmacol. 61 (2008) 721-725. doi:10.1007/s00280-007-0526-4.

[148] S. Mezouar, D. Mege, R. Darbousset, D. Farge, P. Debourdeau, F. Dignat-George, et al., Involvement of Platelet-Derived Microparticles in Tumor Progression and Thrombosis, Semin. Oncol. 41 (2014) 346-358. doi:10.1053/j.seminoncol.2014.04.010.

[149] H.K. Kim, K.S. Song, Y.S. Park, Y.H. Kang, Y.J. Lee, K.R. Lee, et al., Elevated levels of circulating platelet microparticles, VEGF, IL-6 and RANTES in patients with gastric cancer: possible role of a metastasis predictor, Eur. J. Cancer Oxf. Engl. 1990. 39 (2003) 184-191.

[150] D. Helley, E. Banu, A. Bouziane, A. Banu, F. Scotte, A.-M. Fischer, et al., Platelet microparticles: a potential predictive factor of survival in hormone-refractory prostate cancer patients treated with docetaxel-based chemotherapy, Eur. Urol. 56 (2009) 479484. doi:10.1016/j.eururo.2008.06.038.

[151] A.C. Matzdorff, G. Kühnel, B. Kemkes-Matthes, H. Pralle, Quantitative assessment of platelets, platelet microparticles, and platelet aggregates with flow cytometry, J. Lab. Clin. Med. 131 (1998) 507-517. 
[152] A.A. Khorana, C.W. Francis, E. Culakova, G.H. Lyman, Risk factors for chemotherapy-associated venous thromboembolism in a prospective observational study, Cancer. 104 (2005) 2822-2829. doi:10.1002/cncr.21496.

[153] C. Ay, R. Simanek, R. Vormittag, D. Dunkler, G. Alguel, S. Koder, et al., High plasma levels of soluble P-selectin are predictive of venous thromboembolism in cancer patients: results from the Vienna Cancer and Thrombosis Study (CATS), Blood. 112 (2008) 2703-2708. doi:10.1182/blood-2008-02-142422.

[154] H. Mutlu, T.A. Artis, A. Erden, Z. Akca, Alteration in mean platelet volume and platicrit values in patients with cancer that developed thrombosis, Clin. Appl. Thromb. Off. J. Int. Acad. Clin. Appl. Thromb. 19 (2013) 331-333. doi:10.1177/1076029611433644.

[155] A.A. Khorana, N.M. Kuderer, E. Culakova, G.H. Lyman, C.W. Francis, Development and validation of a predictive model for chemotherapy-associated thrombosis, Blood. 111 (2008) 4902-4907. doi:10.1182/blood-2007-10-116327.

[156] I. Pabinger, J. Thaler, C. Ay, Biomarkers for prediction of venous thromboembolism in cancer, Blood. 122 (2013) 2011-2018. doi:10.1182/blood-201304-460147.

[157] K. Vanschoonbeek, M. a. H. Feijge, R.J.W. Van Kampen, H. Kenis, H.C. Hemker, P.L.A. Giesen, et al., Initiating and potentiating role of platelets in tissue factor-induced thrombin generation in the presence of plasma: subject-dependent variation in thrombogram characteristics, J. Thromb. Haemost. JTH. 2 (2004) 476-484.

[158] M. Wahrenbrock, L. Borsig, D. Le, N. Varki, A. Varki, Selectin-mucin interactions as a probable molecular explanation for the association of Trousseau syndrome with mucinous adenocarcinomas, J. Clin. Invest. 112 (2003) 853-862. doi:10.1172/JCI18882.

[159] J.H. Clark, N.P. Kinnear, S. Kalujnaia, G. Cramb, S. Fleischer, L.H. Jeyakumar, et al., Identification of functionally segregated sarcoplasmic reticulum calcium stores in pulmonary arterial smooth muscle, J. Biol. Chem. 285 (2010) 13542-13549. doi:10.1074/jbc.M110.101485.

[160] M. Demers, D.D. Wagner, Neutrophil extracellular traps: A new link to cancerassociated thrombosis and potential implications for tumor progression, Oncoimmunology. 2 (2013) e22946. doi:10.4161/onci.22946.

[161] A.M. Algra, P.M. Rothwell, Effects of regular aspirin on long-term cancer incidence and metastasis: a systematic comparison of evidence from observational studies versus randomised trials, Lancet Oncol. 13 (2012) 518-527. doi:10.1016/S14702045(12)70112-2.

[162] T. Stürmer, R.J. Glynn, I.M. Lee, J.E. Manson, J.E. Buring, C.H. Hennekens, Aspirin use and colorectal cancer: post-trial follow-up data from the Physicians' Health Study, 
Ann. Intern. Med. 128 (1998) 713-720.

[163] N.R. Cook, I.-M. Lee, J.M. Gaziano, D. Gordon, P.M. Ridker, J.E. Manson, et al., Lowdose aspirin in the primary prevention of cancer: the Women's Health Study: a randomized controlled trial, JAMA. 294 (2005) 47-55. doi:10.1001/jama.294.1.47.

[164] Collaborative overview of randomised trials of antiplatelet therapy--III: Reduction in venous thrombosis and pulmonary embolism by antiplatelet prophylaxis among surgical and medical patients. Antiplatelet Trialists' Collaboration, BMJ. 308 (1994) 235-246.

[165] K. Lacut, J. van der Maaten, G. Le Gal, G. Cornily, D. Mottier, E. Oger, Antiplatelet drugs and risk of venous thromboembolism: results from the EDITH case-control study, Haematologica. 93 (2008) 1117-1118. doi:10.3324/haematol.12331.

[166] C. Becattini, G. Agnelli, A. Schenone, S. Eichinger, E. Bucherini, M. Silingardi, et al., Aspirin for preventing the recurrence of venous thromboembolism, N. Engl. J. Med. 366 (2012) 1959-1967. doi:10.1056/NEJMoa1114238.

[167] T.A. Brighton, J.W. Eikelboom, K. Mann, R. Mister, A. Gallus, P. Ockelford, et al., Low-Dose Aspirin for Preventing Recurrent Venous Thromboembolism, N. Engl. J. Med. 367 (2012) 1979-1987. doi:10.1056/NEJMoa1210384.

[168] A. Palumbo, M. Cavo, S. Bringhen, E. Zamagni, A. Romano, F. Patriarca, et al., Aspirin, warfarin, or enoxaparin thromboprophylaxis in patients with multiple myeloma treated with thalidomide: a phase III, open-label, randomized trial, J. Clin. Oncol. Off. J. Am. Soc. Clin. Oncol. 29 (2011) 986-993. doi:10.1200/JC0.2010.31.6844.

[169] I.I. Wistuba, J.G. Gelovani, J.J. Jacoby, S.E. Davis, R.S. Herbst, Methodological and practical challenges for personalized cancer therapies, Nat. Rev. Clin. Oncol. 8 (2011) 135-141. doi:10.1038/nrclinonc.2011.2. 
Figure legends:

Figure 1: Schematic representation of platelets involvement in cancer-associated immunothrombosis. Platelets are key actors of thrombosis and inflammation related to cancer progression. Following their activation, platelets overexpressed different proteins at their surface, released their granules contains and secreted microparticles. These different elements participate in tumor progression (tumor growth, metastasis development or angiogenesis; in red), in inflammation (in blue) and in Trousseau syndrome (in green).

Table legends:

Table 1: Experimental investigations targeting platelets during cancer.

Table 2: Experimental investigations targeting platelets activation during cancer.

Table 3: Experimental investigations targeting contents of platelet granules during cancer.

Table 4: Experimental investigations targeting platelet interactions during cancer. 


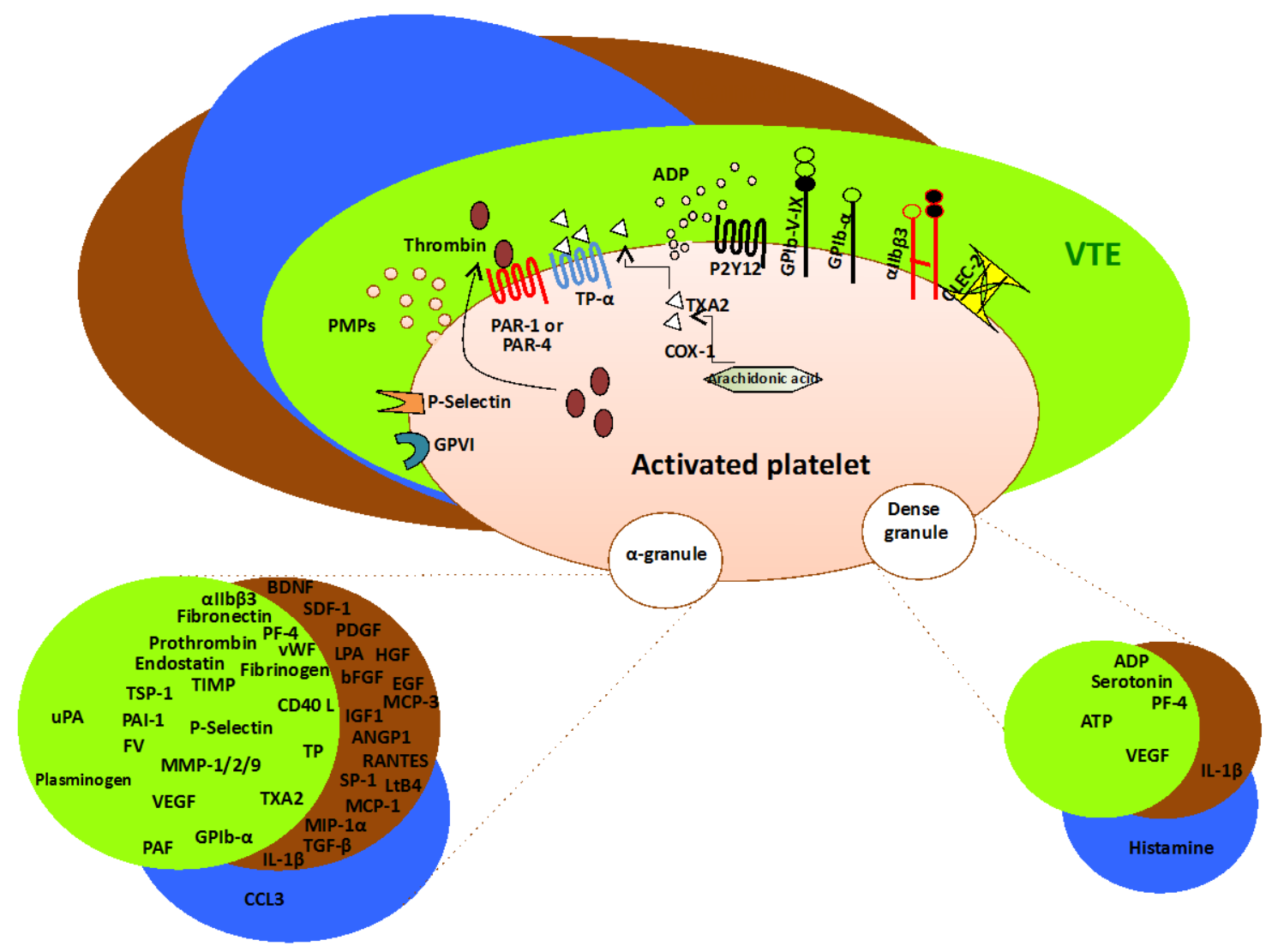

Fig. 1 
Table 1 Experimental investigations targeting platelets in cancer (Ch:Chemical; Em: Experimental metastasis; Ec: Ectopic; Ge:Genetic, MET: Epithelial-mesenchymal transition; Or:Orthotopic;).

\begin{tabular}{|c|c|c|c|c|c|c|}
\hline $\begin{array}{l}\text { Platelet } \\
\text { target } \\
\text { (Physiologic } \\
\text { al functions) }\end{array}$ & $\begin{array}{l}\text { Implication } \\
\text { in } \\
\text { malignancy }\end{array}$ & Experimentation & Impac & malignancy & $\begin{array}{l}\text { Experiment } \\
\text { al model }\end{array}$ & $\begin{array}{c}\text { Referenc } \\
\text { es }\end{array}$ \\
\hline \multirow{3}{*}{$\begin{array}{c}\text { Platelets } \\
\text { (Hemostasis } \\
\text { ) }\end{array}$} & \multirow{3}{*}{$\begin{array}{c}\text { Tumor } \\
\text { growth } \\
\text { Angiogenes } \\
\text { is } \\
\text { Metastasis } \\
\text { TCIPA, } \\
\text { MET } \\
\text { Tumor cells } \\
\text { invasion }\end{array}$} & $\begin{array}{ll}- & \text { Antibody induced } \\
\text { thrombocytopenia } \\
- & \text { Genetic depletion }\end{array}$ & - & $\begin{array}{l}\text { Inhibition of } \\
\text { lung metastasis } \\
\rightarrow \text { Rescue by } \\
\text { restoration of } \\
\text { human platelet } \\
\text { count Decrease } \\
\text { of angiogenesis }\end{array}$ & Em & [3] [4] \\
\hline & & $\begin{array}{l}\text { Neuramidase in mice } \\
\text { bearing a tumor }\end{array}$ & • & $\begin{array}{l}\text { Reduction by } \\
50 \% \text { of } \\
\text { metastases and } \\
\text { thrombocytope } \\
\text { nia }\end{array}$ & Em & [5] [1] \\
\hline & & $\begin{array}{l}\text { Thrombocytopenia in } \\
\text { mice bearing a lung or } \\
\text { melanoma cancer }\end{array}$ & • & $\begin{array}{l}\text { Intra-tumor } \\
\text { hemorrhage } \\
\text { involved by an } \\
\text { absence of } \\
\text { secretion of } \\
\text { platelet } \\
\text { granules }\end{array}$ & Ec & [6] \\
\hline Nfed-2 & - & $\begin{array}{l}\text { Nfed-2 }(\%) \text { (induce a } \\
\text { thrombocytopenia) }\end{array}$ & $\bullet$ & $\begin{array}{l}\text { Decrease of } \\
\text { lung metastasis }\end{array}$ & Em & [7] \\
\hline
\end{tabular}


Table 2 Experimental investigations targeting platelets activation in cancer (Gnbp: Guanine-nucleotide-binding protein; Em: Experimental metastasis; Ec: Ectopic; Or:Orthotopic; Ch:Chemical; Ge:Genetic).

\begin{tabular}{|c|c|c|c|c|c|c|}
\hline $\begin{array}{c}\text { Platelet } \\
\text { target } \\
\text { (Physiologic } \\
\text { al functions) }\end{array}$ & $\begin{array}{l}\text { Implication } \\
\text { in } \\
\text { malignancy }\end{array}$ & Experimentation & Impa & malignancy & $\begin{array}{l}\text { Experiment } \\
\text { al model }\end{array}$ & $\begin{array}{l}\text { Reference } \\
\quad \mathrm{S}\end{array}$ \\
\hline $\begin{array}{c}\text { Gnbp } \\
\text { (Platelet } \\
\text { activation) }\end{array}$ & Metastasis & - $\quad$ Mice lacking G $\alpha q$ & $\bullet$ & $\begin{array}{l}\text { Decrease of } \\
\text { spontaneous and } \\
\text { experimental } \\
\text { metastasis } \\
\rightarrow \text { Reversed by } \\
\text { immunologic or } \\
\text { genetic depletion } \\
\text { of NK cells }\end{array}$ & Em and Or & {$[25]$} \\
\hline \multirow{3}{*}{$\begin{array}{l}\text { Thrombin } \\
\text { (Platelet } \\
\text { activation) }\end{array}$} & \multirow{3}{*}{$\begin{array}{c}\text { Metastasis } \\
\text { TCIPA } \\
\text { VTE } \\
\text { Tumor } \\
\text { growth } \\
\text { Angiogenes } \\
\text { is }\end{array}$} & $\begin{array}{ll}\text { - } & \text { Pretreatment of } \\
\text { cancer cells with } \\
\text { thrombin } \\
\text { Preinfusion of } \\
\text { thrombin into mice }\end{array}$ & • & $\begin{array}{l}\text { Enhance } 4-400 \\
\text { fold of } \\
\text { experimental } \\
\text { lung metastasis } \\
\text { Enhance } 10-160 \\
\text { fold of } \\
\text { experimental } \\
\text { lung metastasis }\end{array}$ & Em & [3] \\
\hline & & $\begin{array}{l}\text { Dansylarginine N- } \\
\text { (3-ethyl-1,5- } \\
\text { pentanediyl) amide } \\
\text { a specific thrombin } \\
\text { inhibitor }\end{array}$ & $\bullet$ & $\begin{array}{l}\text { Inhibition of } \\
\text { TCIPA of human } \\
\text { colon } \\
\text { adenocarcinomas } \\
\text { and anaplastic } \\
\text { mouse tumor }\end{array}$ & Em & [26] \\
\hline & & $\begin{array}{l}\text { Bivalirudin drug } \\
\text { FM19 an reversible } \\
\text { direct thrombin } \\
\text { inhibitor }\end{array}$ & $\bullet$ & $\begin{array}{l}\text { Decrease prostate } \\
\text { cancer cell } \\
\text { invasion, tumor } \\
\text { growth (size and } \\
\text { weight) and } \\
\text { angiogenesis }\end{array}$ & $\mathrm{Ec}$ & [27] \\
\hline $\begin{array}{c}\text { TXA2 } \\
\text { (Platelet } \\
\text { activation) }\end{array}$ & & $\begin{array}{l}\text { OKY }-046 \\
\text { (Inhibition of TXA2 } \\
\text { synthase) }\end{array}$ & $\bullet$ & $\begin{array}{l}\text { No effect on } \\
\text { osteogenic } \\
\text { sarcoma cell } \\
\text { induce TCIPA }\end{array}$ & In vitro & {$[28]$} \\
\hline \multirow{6}{*}{$\begin{array}{c}\text { ADP } \\
\text { (Platelet } \\
\text { activation, } \\
\text { adhesion } \\
\text { and } \\
\text { aggregation } \\
\text { ) }\end{array}$} & \multirow{6}{*}{$\begin{array}{l}\text { Metastasis } \\
\text { TCIPA } \\
\text { Activation } \\
\text { of platelets } \\
\text { and release } \\
\text { of VEGF }\end{array}$} & $\begin{array}{l}-\quad \text { Ticagrelor treatment } \\
(10 \mathrm{mg} / \mathrm{Kg})\end{array}$ & • & $\begin{array}{l}\text { Reduction of } \\
\text { lung and liver } \\
\text { metastases } \\
\text { Inhibit platelet/ } \\
\text { cancer cells } \\
\text { interaction }\end{array}$ & Em and Ec & [29] \\
\hline & & $\begin{array}{l}\text { Clopidogrel } \\
\text { treatment } \\
(8 \mathrm{mg} / \mathrm{Kg} / \text { day })\end{array}$ & $\bullet$ & $\begin{array}{l}\text { Decrease tumor } \\
\text { growth; } \\
\text { metastasis and } \\
\text { thrombosis } \\
\text { associated with } \\
\text { cancer in } \\
\text { pancreatic mice } \\
\text { models }\end{array}$ & Or and Ec & [30] \\
\hline & & $\begin{array}{l}\text { APT102 } \\
\text { (Apyrase/ADPase; } \\
\text { mutated form of } \\
\text { CD39) + Aspirin }\end{array}$ & $\bullet$ & $\begin{array}{l}\text { Decrease breast } \\
\text { cancer and } \\
\text { melanoma bone } \\
\text { metastasis } \\
\text { Diminish TCIPA; } \\
\text { without bleeding }\end{array}$ & Em and Ec & [31] \\
\hline & & $\begin{array}{l}\text { SR } 25989 \\
\text { thienopyridine } \\
\text { (enantiomer of } \\
\text { Clopidogrel) } \\
\text { Ticlopidine (P2Y } \\
\text { antagonist) }\end{array}$ & $\bullet$ & $\begin{array}{l}\text { Inhibit } \\
\text { angiogenesis (by } \\
\text { thrombospondin- } \\
1 \text { release) } \\
\text { Inhibit metastasis } \\
\text { dissemination } \\
\text { and growth }\end{array}$ & $\begin{array}{l}\text { Ec , Em and } \\
\text { in vitro }\end{array}$ & $\begin{array}{c}{[32][33][3} \\
4]\end{array}$ \\
\hline & & Apyrase $(250 \mu \mathrm{g} / \mathrm{ml})$ & $\bullet$ & $\begin{array}{l}\text { Reduce TCIPA; } \\
\text { Inhibition of } \\
\text { platelet function }\end{array}$ & In vitro & {$[19][35]$} \\
\hline & & $\begin{array}{l}\text { MRS2179 (P2Y } \\
\text { antagonist) } \\
\text { Cangrelor (P2Y } 12\end{array}$ & $\bullet$ & $\begin{array}{l}\text { Inhibition of } \\
\text { VEGF } \\
\text { Minimal increase }\end{array}$ & In vitro & [36] \\
\hline
\end{tabular}




\begin{tabular}{|c|c|c|c|c|c|c|c|}
\hline & & & antagonist) & & of endostatin & & \\
\hline & & $\bullet$ & 2-methylthio-AMP & $\bullet$ & Decrease TCIPA & In vitro & [18] \\
\hline $\begin{array}{c}\text { PARs } \\
\text { (Platelet } \\
\text { activation } \\
\text { by } \\
\text { thrombin) }\end{array}$ & $\begin{array}{l}\text { Metastasis } \\
\text { TCIPA }\end{array}$ & $\begin{array}{l}\bullet \\
\bullet \\
\bullet\end{array}$ & $\begin{array}{l}\text { PAR-4 }\left({ }^{\prime}\right) \\
\text { PAR-4 } \\
\text { heterozygosity mice } \\
\text { PAR-1 and PAR-2 ( } \\
\left.I^{\prime}\right)\end{array}$ & - & $\begin{array}{l}\text { Decrease } \\
\text { metastasis } \\
\text { Some protection } \\
\text { to metastasis } \\
\text { No metastasis } \\
\text { protection }\end{array}$ & Em & [7] \\
\hline \multirow{11}{*}{$\begin{array}{c}\text { COX-1 } \\
\text { COX-2 } \\
\text { (Platelet } \\
\text { activation } \\
\text { by TXA }{ }_{2} \text { ) }\end{array}$} & \multirow{11}{*}{$\begin{array}{c}\text { TCIPA } \\
\text { Tumor } \\
\text { growth } \\
\text { Angiogenes } \\
\text { is } \\
\text { Metastasis }\end{array}$} & $\bullet$ & Aspirin & $\bullet$ & $\begin{array}{l}\text { Inhibition of the } \\
\text { release of } \\
\text { activated } \\
\text { platelets }\end{array}$ & In vitro & [37] \\
\hline & & $\bullet$ & $\begin{array}{l}\text { Aspirin }(100 \mathrm{mg} / \mathrm{Kg} \\
\text { twice a day) }\end{array}$ & $\bullet$ & $\begin{array}{l}\text { Inhibition of } \\
\text { lymph node } \\
\text { metastasis }\end{array}$ & Or & {$[38]$} \\
\hline & & - & $\begin{array}{l}\text { ST0702 (nicotinate } \\
\text { aspirin prodrug) }\end{array}$ & $\bullet$ & $\begin{array}{l}\text { Inhibition of } \\
\text { TCIPA }\end{array}$ & In vitro & [39] \\
\hline & & - & $\begin{array}{l}\text { Aspirin low dose } \\
(5 \mathrm{mg} / \mathrm{Kg})\end{array}$ & $\bullet$ & $\begin{array}{l}\text { Prevent cancer } \\
\text { and increase the } \\
\text { survival in mice } \\
\text { models }\end{array}$ & $\mathrm{Ch}$ and $\mathrm{Ge}$ & [40] \\
\hline & & $\bullet$ & Aspirin & $\bullet$ & $\begin{array}{l}\text { Suppression of } \\
\text { VEGF release } \\
\text { from platelets }\end{array}$ & In vitro & [41] \\
\hline & & $\bullet$ & $\begin{array}{l}\text { Aspirin }(80,100 \text { and } \\
150 \mathrm{mg} / \mathrm{Kg} / \text { day })\end{array}$ & $\bullet$ & $\begin{array}{l}\text { Decrease of } \\
\text { tumor growth in } \\
\text { melanoma mice } \\
\text { model }\end{array}$ & Ec & [42] \\
\hline & & $\bullet$ & $\begin{array}{l}\text { Aspirin high dose } \\
\text { ( } 200 \text { or } 400 \\
\mathrm{mg} / \mathrm{Kg} / \text { day) }\end{array}$ & $\bullet$ & $\begin{array}{l}\text { Increase tumor } \\
\text { growth, cell } \\
\text { proliferation, } \\
\text { angiogenesis }\end{array}$ & Ec & [43] \\
\hline & & $\bullet$ & $\begin{array}{l}\text { Aspirin treatment } \\
(10 \mathrm{mg} / \mathrm{Kg} / \text { day })\end{array}$ & $\bullet$ & $\begin{array}{l}\text { Decrease } \\
\text { metastasis in } \\
\text { pancreatic mice } \\
\text { model }\end{array}$ & Or & [44] \\
\hline & & $\bullet$ & Aspirin $(100 \mu \mathrm{M})$ & $\bullet$ & $\begin{array}{l}\text { Reduce TCIPA; } \\
\text { Inhibition of } \\
\text { platelet function }\end{array}$ & In vitro & {$[19][45]$} \\
\hline & & $\bullet$ & Aspirin $(50 \mu \mathrm{g} / \mathrm{ml})$ & $\bullet$ & $\begin{array}{l}\text { Inhibit TCIPA of } \\
\text { human breast } \\
\text { cancer cell }\end{array}$ & In vitro & [46] \\
\hline & & $\bullet$ & $\begin{array}{l}\text { Aspirin low dose } \\
\text { (12,5 or } 25 \\
\mathrm{mg} / \mathrm{Kg} / \mathrm{day})\end{array}$ & $\bullet$ & $\begin{array}{l}\text { Decrease tumor } \\
\text { growth }\end{array}$ & Ec & [43] \\
\hline
\end{tabular}


Table 3 Experimental investigations targeting contents of the granules of platelets (Em: Experimental metastasis; Ec: Ectopic; Or:Orthotopic; Ch:Chemical; Ge:Genetic).

\begin{tabular}{|c|c|c|c|c|c|c|c|}
\hline $\begin{array}{l}\text { Platelet target } \\
\text { (Physiological } \\
\text { functions) }\end{array}$ & \multirow{3}{*}{$\begin{array}{l}\text { Implication } \\
\text { in } \\
\text { malignancy }\end{array}$} & \multicolumn{2}{|c|}{ Experimentation } & \multicolumn{2}{|c|}{ Impact on malignancy } & \multirow{2}{*}{$\begin{array}{l}\text { Experiment } \\
\text { al model } \\
\text { In vitro }\end{array}$} & \multirow{2}{*}{$\begin{array}{l}\text { Reference } \\
\text { S } \\
{[53][54]}\end{array}$} \\
\hline & & $\bullet$ & $\begin{array}{l}\text { IGFR-1 blocking } \\
\text { antibody }\end{array}$ & $\bullet$ & $\begin{array}{l}\text { Inhibit the } \\
\text { breast tumor } \\
\text { growth }\end{array}$ & & \\
\hline $\begin{array}{c}\text { IGF-1 } \\
\text { (Angiogenesi } \\
\text { s) }\end{array}$ & & $\bullet$ & $\begin{array}{l}\text { Pegvisomant (GH } \\
\text { receptor antagonist) }\end{array}$ & $\bullet$ & $\begin{array}{l}\text { Inhibit } \\
\text { metastatic colon } \\
\text { cancer in } \\
\text { combination } \\
\text { with } \\
\text { chemotherapy } \\
\text { and breast } \\
\text { cancer cell }\end{array}$ & Em & {$[55]$} \\
\hline \multirow{4}{*}{$\begin{array}{c}\text { VEGF } \\
\text { (Angiogenesi } \\
\text { s) }\end{array}$} & \multirow{4}{*}{$\begin{array}{c}\text { Angiogenesi } \\
\text { s } \\
\text { Tumor } \\
\text { growth }\end{array}$} & $\bullet$ & Bevacizumab & $\bullet$ & $\begin{array}{l}\text { Decrease of } \\
\text { invasiveness of } \\
\text { cancer cell }\end{array}$ & In vitro & {$[56]$} \\
\hline & & $\bullet$ & $\begin{array}{l}\text { Pazopanib (tyrosine } \\
\text { kinase inhibitor) }\end{array}$ & $\bullet$ & $\begin{array}{l}\text { Antitumor } \\
\text { activity in renal } \\
\text { cell carcinoma }\end{array}$ & In vitro & [57] \\
\hline & & $\bullet$ & $\begin{array}{l}\text { Vatalanib } \\
\text { PTK787/ZK } 222584 \\
\text { (Tyrosine kinase } \\
\text { inhibitor) }\end{array}$ & $\bullet$ & $\begin{array}{l}\text { Inhibit growth } \\
\text { tumor and } \\
\text { metastasis }\end{array}$ & Ec and Or & {$[58]$} \\
\hline & & $\bullet$ & $\begin{array}{l}\text { Sunitinib SU11248 } \\
\text { (tyrosine kinase } \\
\text { inhibitor) }\end{array}$ & $\bullet$ & $\begin{array}{l}\text { Anti tumor and } \\
\text { angiogenic } \\
\text { activity }\end{array}$ & Ec & [59] \\
\hline $\begin{array}{c}\text { TGF- } \beta \\
\text { (Cell } \\
\text { proliferation, } \\
\text { and } \\
\text { migration) }\end{array}$ & $\begin{array}{l}\text { Cell } \\
\text { proliferation } \\
\rightarrow \text { resistance } \\
\text { by cancer } \\
\quad \text { cells }\end{array}$ & $\bullet$ & $\begin{array}{l}2 \mathrm{G} 7 \text { neutralizing } \\
\text { antibody }\end{array}$ & $\begin{array}{l}\bullet \\
\bullet\end{array}$ & $\begin{array}{l}\text { Moderate } \\
\text { inhibition of } \\
\text { tumor growth } \\
\text { Block } \\
\text { metastasis }\end{array}$ & In vitro & {$[60]$} \\
\hline $\begin{array}{c}\text { PDGF } \\
\text { (Angiogenesi } \\
\text { s) }\end{array}$ & $\begin{array}{c}\text { Angiogenesi } \\
\text { s } \\
\text { Tumor } \\
\text { growth }\end{array}$ & $\bullet$ & $\begin{array}{l}\text { STI571 inhibit the } \\
\text { phosphorylation of } \\
\text { PDGF-R }\end{array}$ & $\bullet$ & $\begin{array}{l}\text { Inhibition of } \\
\text { human prostate } \\
\text { cancer bone } \\
\text { metastasis }\end{array}$ & $\mathrm{Ec}$ & {$[61]$} \\
\hline $\begin{array}{c}\text { EGF } \\
\text { (Angiogenesi } \\
\text { s) }\end{array}$ & $\begin{array}{l}\text { Angiogenesi } \\
\text { s } \\
\text { Tumor } \\
\text { growth }\end{array}$ & $\bullet$ & $\begin{array}{l}\text { PKI166 inhibit the } \\
\text { phosphorylation of } \\
\text { EGF-R }\end{array}$ & $\bullet$ & $\begin{array}{l}\text { Inhibition of } \\
\text { human prostate } \\
\text { cancer bone } \\
\text { metastasis }\end{array}$ & Ec & {$[61]$} \\
\hline \multirow{8}{*}{$\begin{array}{l}\text { MMPs } \\
\text { (Matrix } \\
\text { degradation } \\
\text { Remodeling } \\
\text { of tissue) }\end{array}$} & \multirow{8}{*}{$\begin{array}{l}\text { Tumor cells } \\
\text { invasion } \\
\text { Angiogenesi } \\
\text { s } \\
\text { Metastasis } \\
\text { TCIPA }\end{array}$} & $\bullet$ & $\begin{array}{l}\text { Antisense RNA } \\
\text { decrease MMP-1 }\end{array}$ & $\bullet$ & $\begin{array}{l}\text { Decrease the } \\
\text { invasiveness }\end{array}$ & In vitro & {$[62]$} \\
\hline & & $\bullet$ & MMP-8 $(\%)$ & $\bullet$ & $\begin{array}{l}\text { Increase of } \\
\text { papillomas } \\
\text { (carcinogen } \\
\text { treatment) }\end{array}$ & $\mathrm{Ch}$ & [63] \\
\hline & & $\bullet$ & MMP-2 $(\digamma)$ & $\bullet$ & $\begin{array}{l}\text { Inhibit tumor } \\
\text { induce } \\
\text { angiogenesis }\end{array}$ & Ec and Or & [64] \\
\hline & & $\bullet$ & MMP-9 $(\%)$ & $\bullet$ & $\begin{array}{l}\text { Inhibit } \\
\text { angiogenesis } \\
\text { and metastasis }\end{array}$ & Em and Or & [65] \\
\hline & & $\bullet$ & $\begin{array}{l}\text { Curcumin (inhibit } \\
\text { MMP-9 expression) }\end{array}$ & $\bullet$ & $\begin{array}{l}\text { Inhibit cell } \\
\text { invasion }\end{array}$ & & {$[66]$} \\
\hline & & $\bullet$ & $\begin{array}{l}\text { DX-2400 (MMP-14 } \\
\text { inhibitory antibody) }\end{array}$ & $\bullet$ & $\begin{array}{l}\text { Inhibit } \\
\text { angiogenesis, } \\
\text { tumor growth } \\
\text { and metastasis } \\
\text { lesion }\end{array}$ & Or and Ec & [67] \\
\hline & & $\bullet$ & $\begin{array}{l}\text { Phenanthroline } \\
\text { (inhibitor of MMPs) } \\
\text { and neutralizing } \\
\text { antibodies anti } \\
\text { MMP-2 }\end{array}$ & $\bullet$ & $\begin{array}{l}\text { Reduce TCIPA } \\
\text { Inhibition of } \\
\text { platelet function }\end{array}$ & In vitro & [68] \\
\hline & & $\bullet$ & $\begin{array}{l}\text { Letrozole (inhibitor } \\
\text { of MMP-2 and } \\
\text { MMP-9) }\end{array}$ & $\bullet$ & $\begin{array}{l}\text { Inhibit cell } \\
\text { proliferation, } \\
\text { tumor growth } \\
\text { and }\end{array}$ & In vitro & [69] \\
\hline
\end{tabular}




\begin{tabular}{llll}
\hline$\bullet$ & $\begin{array}{l}\text { Gebistein }(\text { decrease } \\
\text { MMP-2) }\end{array}$ & $\bullet$ & $\begin{array}{l}\text { Decrease tumor } \\
\text { cell invasion }\end{array}$
\end{tabular}


Table 4 Experimental investigations targeting platelet interactions in cancer (Em: Experimental metastasis; Ec: Ectopic; Or:Orthotopic; Ch:Chemical; Ge:Genetic).

\begin{tabular}{|c|c|c|c|c|c|c|}
\hline $\begin{array}{l}\text { Platelet target } \\
\text { (Physiological } \\
\text { functions) }\end{array}$ & $\begin{array}{l}\text { Implication } \\
\text { in } \\
\text { malignancy }\end{array}$ & Experimentation & Impa & malignancy & $\begin{array}{l}\text { Experiment } \\
\text { al model }\end{array}$ & $\begin{array}{c}\text { Referenc } \\
\text { es }\end{array}$ \\
\hline $\begin{array}{l}\text { GPVI } \\
\text { (Activation, } \\
\text { adhesion and } \\
\text { aggregation) }\end{array}$ & Metastasis & $\operatorname{GPVI}\left({ }^{-}\right)$ & $\bullet$ & $\begin{array}{l}\text { Decrease } \\
\text { metastasis }(50 \% \\
\text { de reduction) }\end{array}$ & $\mathrm{Em}$ and $\mathrm{Ec}$ & [93] \\
\hline \multirow{11}{*}{$\begin{array}{l}\text { P-selectin } \\
\text { (Stabilization of } \\
\text { aggregation, } \\
\text { rolling and } \\
\text { adhesion) }\end{array}$} & \multirow{11}{*}{$\begin{array}{l}\text { Tumor } \\
\text { growth } \\
\text { Metastasis }\end{array}$} & $\begin{array}{ll}- & \text { P-selectin }(\%) \\
\text { Blocking antibody } \\
\text { directed against P- } \\
\text { selectin }\end{array}$ & $\bullet$ & $\begin{array}{l}\text { Decrease tumor } \\
\text { growth, TCIPA } \\
\text { and metastasis } \\
\text { Reduction of } \\
\text { tumor cells } \\
\text { survival }\end{array}$ & Em and Ec & {$[94][95]$} \\
\hline & & $\begin{array}{l}\text { Heparin } \\
\text { tetrasaccharides } \\
\text { treatment }\end{array}$ & $\bullet$ & $\begin{array}{l}\text { Block colon } \\
\text { cancer cell } \\
\text { adhesion to P- } \\
\text { selectin }\end{array}$ & In vitro & [96] \\
\hline & & Heparin treatment & $\bullet$ & $\begin{array}{l}\text { Inhibition of } \\
\text { platelet and } \\
\text { cancer cells } \\
\text { interactions }\end{array}$ & Em and Or & [97] \\
\hline & & Heparin treatment & $\bullet$ & $\begin{array}{l}\text { Inhibition of } \\
\text { platelet cancer } \\
\text { cells interaction } \\
\text { and metastasis }\end{array}$ & Em & [98] \\
\hline & & $\begin{array}{l}\text { Disaccharide } \\
\text { precursor of Sialyl } \\
\text { LewisX }\end{array}$ & $\bullet$ & $\begin{array}{l}\text { Inhibit } \\
\text { metastatic } \\
\text { potential of } \\
\text { tumor cells }\end{array}$ & Em & [99] \\
\hline & & $\begin{array}{l}\text { P- and L-Selectin } \\
\text { double }\left({ }^{-}\right) \\
\text {Heparin treatment }\end{array}$ & $\bullet$ & $\begin{array}{l}\text { Inhibition of } \\
\text { platelet P- } \\
\text { selectin } \\
\text { interaction with } \\
\text { cancer cells via } \\
\text { a sulfated } \\
\text { glycolipid }\end{array}$ & Em & [100] \\
\hline & & $\begin{array}{l}\text { Blocking } \\
\text { antibodies or } \\
\text { neuramidase and } \\
\text { trypsin treatments }\end{array}$ & $\bullet$ & $\begin{array}{l}\text { Inhibition of } \\
\text { platelet } \mathrm{P} \text { - } \\
\text { selectin and } \\
\text { cancer cells } \\
\text { interaction }\end{array}$ & In vitro & [101] \\
\hline & & P-selectin $\left({ }^{-}\right)$ & $\bullet$ & $\begin{array}{l}\text { Attenuate both } \\
\text { tumor growth } \\
\text { and metastasis }\end{array}$ & Em and Ec & [102] \\
\hline & & P-selectin $\left({ }^{\prime}\right)$ & $\bullet$ & $\begin{array}{l}\text { Reduction of } \\
\text { lung } \\
\text { experimental } \\
\text { metastasis in } \\
\text { mice }\end{array}$ & Em and Ec & [103] \\
\hline & & $\begin{array}{l}\text { O- } \\
\text { Sialoglycoproteas } \\
\text { e treatment } \\
\text { (cleave mucin } \\
\text { type-O-linked } \\
\text { glycoproteins) }\end{array}$ & $\bullet$ & $\begin{array}{l}\text { Inhibition of } \\
\text { adhesion of } \\
\text { colon cancer } \\
\text { cells }\end{array}$ & In vitro & [104] \\
\hline & & $\begin{array}{l}\text { Dermatan sulfates } \\
\text { (interact with P- } \\
\text { selectin) }\end{array}$ & $\bullet$ & $\begin{array}{l}\text { Attenuation of } \\
\text { thrombosis, } \\
\text { metastasis and } \\
\text { leukocytes in } \\
\text { tumor }\end{array}$ & $\mathrm{Em}$ & [105] \\
\hline $\begin{array}{c}\alpha I I b \beta 3 / G P I I b I I \\
\text { Ia } \\
\text { (Adhesion and } \\
\text { aggregation) }\end{array}$ & $\begin{array}{l}\text { Metastasis } \\
\text { Interaction } \\
\text { platelet/canc } \\
\text { er cell (with } \\
\text { fibrinogen, } \\
\text { fibronectin } \\
\text { and vWF) } \\
\text { TCIPA }\end{array}$ & $\begin{array}{l}\text { Preincubation of } \\
\text { human platelets } \\
\text { with 10E5 } \\
\text { antibody } \\
\text { RGDS treatment } \\
\text { or antibodies } \\
\text { directed against } \\
\text { fibronectin and }\end{array}$ & $\begin{array}{l}\bullet \\
\bullet\end{array}$ & $\begin{array}{l}\text { Inhibition of } \\
\text { tumor cells } \\
\text { adhesion to } \\
\text { platelets } \\
\text { Inhibition of } \\
\text { metastasis after } \\
\text { thrombocytopen } \\
\text { ia }\end{array}$ & Em & {$[3][106]$} \\
\hline
\end{tabular}




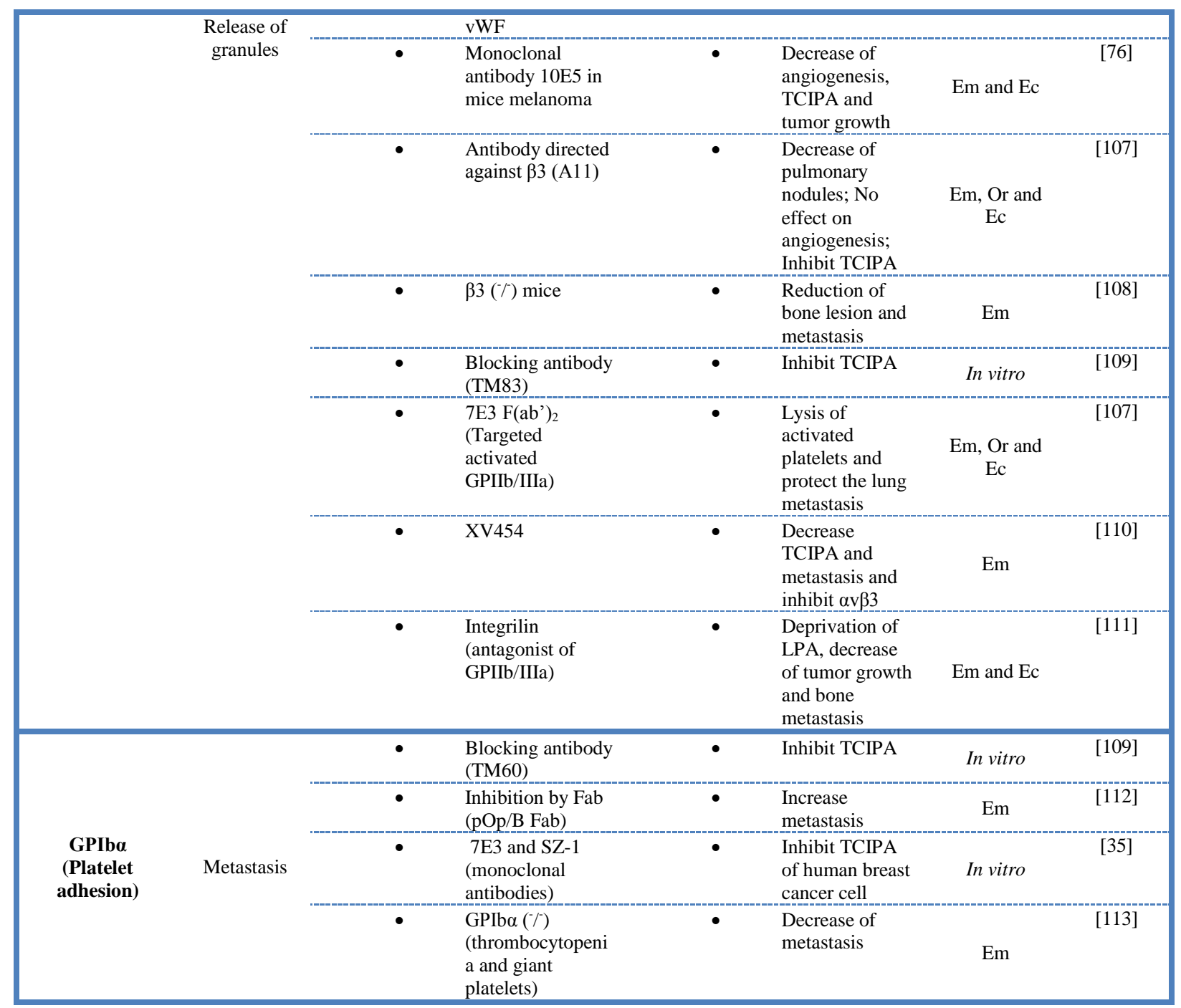

\section{Highlights}

- The role of platelets in cancer progression and metastasis is described

- The mechanisms involved in thrombosis associated with cancer are discussed

- The use of anti platelet or anticoagulant drugs in cancer is considered. 